2. To: (Receiving Organization) Distribution

5. Proj./Prog./Dept./Div.:

Criticality Safety

Evaluation/Technical

Operations/Process

Engineering

3. From: (Originating Organization)
Process Engineering
6. Design Authority/ Design Agent/Cog.
Engr.:

E. V. Weiss
8. Originator Remarks:

This document is being released into the supporting document system for retrievability purposes.

9. Equip./Component No.:

$\mathrm{N} / \mathrm{A}$

10. System/Bldg./Facility:

$\mathrm{N} / \mathrm{A}$
11. Receiver Remarks:
11A. Design Baseline Document?
[] Yes
[X] No

For release.

$$
\mathrm{N} / \mathrm{A}
$$

2. Major Assm. Dwg. No.:

13. Permit/Permit Application No.:

$$
N / A
$$

14. Required Response Date:

$$
08 / 10 / 00
$$

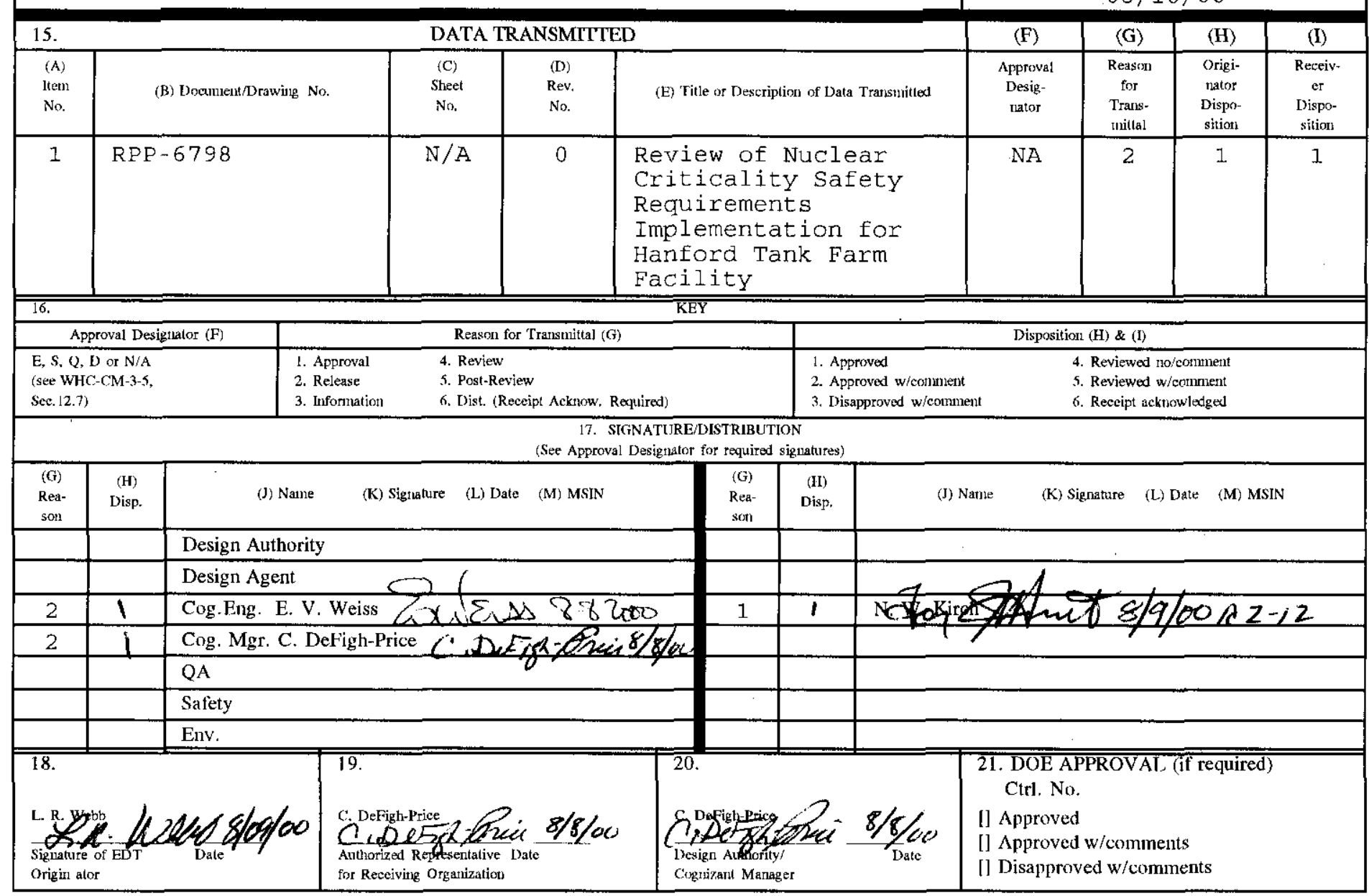

BD-7400-172-2 (05/96) GEF097 


\section{Review of Nuclear Criticality Safety Requirements Implementation for Hanford Tank Farms Facility}

C. DeFigh-Price, E. V. Weiss and N. W. Kirch CH2M HILL Hanford Group, Inc.

Richland, WA 99352

U.S. Department of Energy Contract DE-AC06-99RL14047

$\begin{array}{lll}\text { EDT/ECN: } & \text { EDT }-628396 & \text { UC: } 2070 \\ \text { Cost Center: } 74 \text { B00 } & \text { Charge Code: } 101965 \\ \text { B\&R Code: } & \text { EW } 3120074 & \text { Total Pages: } \mathbf{4 8}\end{array}$

Key Words: criticality, criticality safety, CSR, limited control facility

Abstract: In November 1999, the Deputy Secretary of the Department of Energy directed a series of actions to strengthen the Department's ongoing nuclear criticality safety programs. A Review Plan describing lines of inquiry for assessing contractor programs was included. The Office of River Protection completed their assessment of the Tank Farm Contractor program in May 2000. This document supports that assessment by providing a compliance statement for each Iine of inquiry.

TRADEMARK DISCLAIMER. Reference herein to any specific commercial product, process, or service by trade name, trademark, manufacturer, or otherwise, does not necessarily constitute or imply its endorsement, recommendation, or favoring by the United States Government or any agency thereof or its contractors or subcontractors.

Printed in the United States of America. To obtain copies of this document, contact: Document Control Services, P.O. Box 950, Mailstop H6-08, Richland WA 99352, Phone (509) 372-2420; Fax (509) 376-4989.
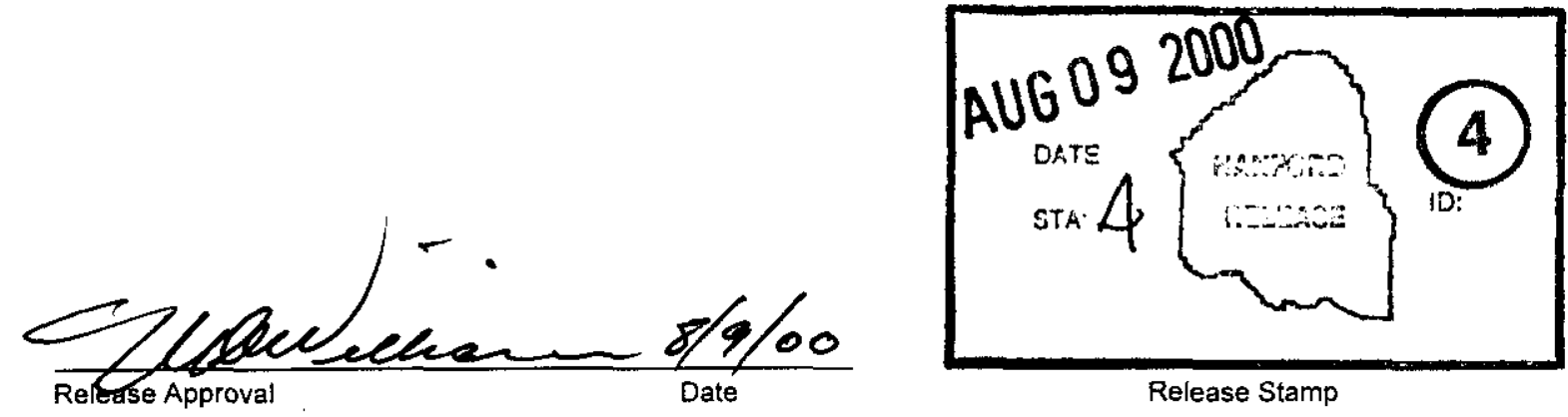

Release Stamp

\section{Approved For Public Release}


RPP-6798

Revision 0

\section{REVIEW OF NUCLEAR CRITICALITY SAFETY REQUIREMENTS IMPLEMENTATION FOR HANFORD TANK FARMS FACILITY}

Cherri DeFigh-Price

Evelyn V. Weiss

Nicolas W. Kirch

CH2M HILL Hanford Group, Inc.

Date Published

August 2000

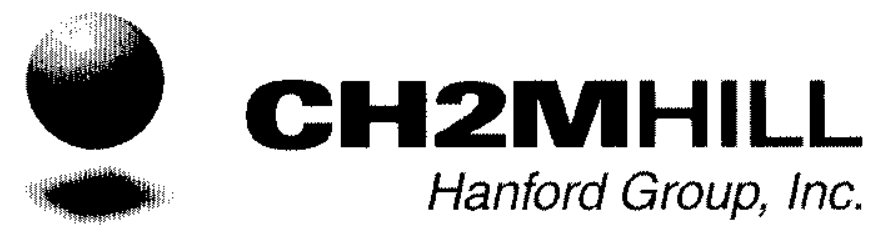

Prepared for the U.S. Department of Energy

Office of River Protection

Approved for public release; distribution unlimited 


\section{EXECUTIVE SUMMARY}

In November 1999, the Deputy Secretary of the Department of Energy (DOE) directed a series of actions to strengthen the Department's ongoing nuclear criticality safety (NCS) programs, including assessment of contractor NCS programs. A Review Plan describing lines of inquiry (LOI) for assessing contractor programs was attached. The Office of River Protection completed their assessment of the Tank Farm Contractor program in May 2000. This document supports that assessment by providing a compliance statement for each LOI that identifies applicable contractor procedures and documents for the Hanford Tank Farms facility. 
This page intentionally left blank 


\section{TABLE OF CONTENTS}

\section{EXECUTIVE SUMMARY}

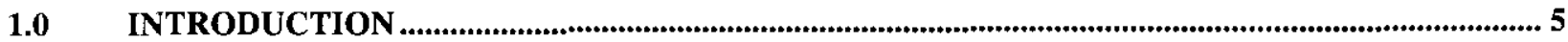

1.1 PURPOSE

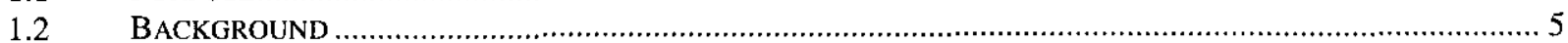

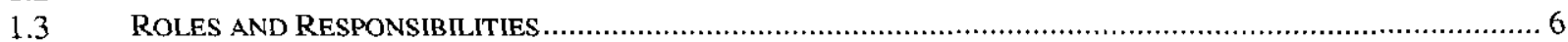

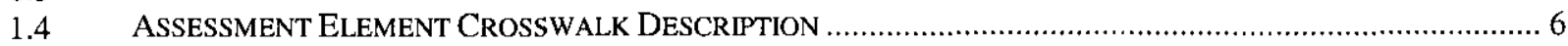

2.0 CROSSWALK OF ASSESSMENT ELEMENTS VERSUS COMPLIANCE STATEMENTS............ 8

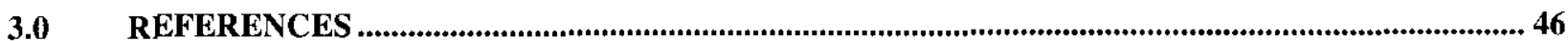


This page intentionally left blank 


\subsection{INTRODUCTION}

\subsection{Purpose}

In November 1999, the Deputy Secretary of the Department of Energy (DOE) directed a series of actions to strengthen the Department's ongoing nuclear criticality safety (NCS) programs, including assessment of contractor NCS programs. A Review Plan describing lines of inquiry (LOI) for assessing contractor programs was attached. The Office of River Protection completed their assessment of the Tank Farm Contractor program in May 2000. This document supports that assessment by providing a compliance statement for each LOI that identifies applicable contractor procedures and documents for the Hanford Tank Farms facility.

\subsection{Background}

CH2M Hill Hanford Group, Inc. (CHG) manages the River Protection Project for the DOE Office of River Protection. The Tank Farms nuclear criticality safety program applies to activities associated with the safe receipt, transfer and storage of waste in the Tank Farms facility. Specifically, the program applies to fissionable materials contained in waste stored in:

- $\quad$ High-level waste (HLW) storage tanks and ancillary equipment,

- Double-contained receiver tanks (DCRTs) and ancillary equipment,

- Miscellaneous inactive storage tanks and equipment (MISFs,

- $\quad$ Ponds, cribs, and ditches.

The current Tank Farms facility mission is to continue to safely store remaining tank waste and to conduct waste retrieval and disposal activities in support of the long-term goal for the complete removal and final disposition of the tank waste. Activities are performed at Tank Farms in a manner that complies with environmental regulations and minimizes public and worker risk.

Collectively, the DSTs and SSTs contain an estimated 500 to $1,000 \mathrm{~kg}(1,100$ to $2,200 \mathrm{lb})$ of plutonium. Analyses of tank waste samples show that the plutonium content of the waste is primarily associated with the sludge phase. WHC-SD-WM-TI-725, Tank Farm Nuclear Criticality Review, established that fissionable material in the waste tanks is distributed at subcritical concentrations with excess neutron absorbers present, and that no mechanisms exist to concentrate the fissile material to result in an accidental nuclear criticality. Related accident analyses are documented in HNF-SD-WM-SAR-067, Tank Waste Remediation System Final Safety Analysis Report (FSAR). Section 6.3.2 of the FSAR states that a criticality accident in the Tank Farms is not credible for operations discussed in that document, and that the facility is classified for the purposes of nuclear criticality safety as a Limited Control Facility. The Tank Farms criticality safety program, therefore, consists primarily of administrative controls designed to protect against altering the waste inventory in a way that could increase the probability of a criticality accident. Controls for the program are discussed in HNF-SD-WM-TSR-006, Tank Waste Remediation System Technical Safety Requirements, Administrative Control 5.7, "Nuclear 
Criticality Safety." The program is described in HNF-IP-1266, Tank Farms Operations

Administrative Controls, Chapter 5.7, "Nuclear Criticality Safety."

\subsection{Roles and Responsibilities}

The criticality safety program at Tank Farms is focused on maintaining the facility status as a Limited Control Facility. Organizationally, the program manager and Criticality Safety Representative (CSR) report to the facility manager from within the engineering function. The CSR is roughly equivalent to a Criticality Safety Officer as called out in some DOE documents. The functional organization chart is shown in Figure 1 below.

\subsection{Assessment Element Crosswalk Description}

A detailed crosswalk of requirements, assessment elements, implementing documents and compliance statements for each is shown in Table 1 later in this document. The table is organized to show:

- Item - a sequential number for ease of reference

- Requirement / Query -- each individual requirement is stated, followed by lines of inquiry (assessment elements or criteria) in the same column. This information is copied from Attachment 3 to the November 1999 Glauthier memorandum (Glauthier).

- Implementing Document - the document number, and in most cases, the section in the Tank Farms Contractor procedural document which implements a particular requirement or provides the background information is identified.

- Compliance Statement - additional text describing the way in which Tank Farms complies with a requirement or a reason why the requirement is not applicable, and

- Corrective Action - in this column, any corrective action that the Department or the Contractor is taking to upgrade compliance for a particular element is described. 
Figure 1. Tank Farms Nuclear Criticality Safety Program

Functional Organization

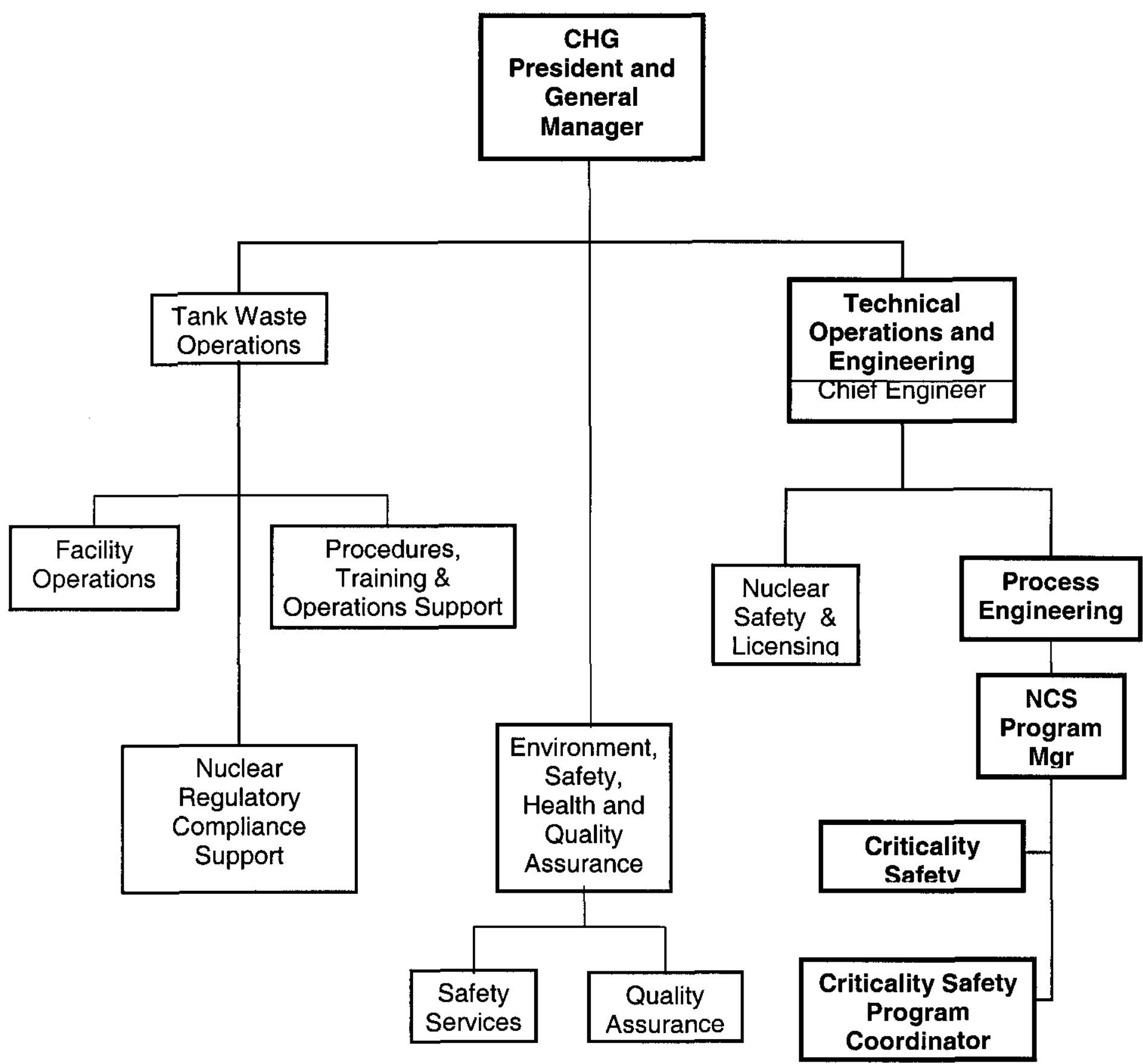

Update: $4 / 24 / 2000$ 


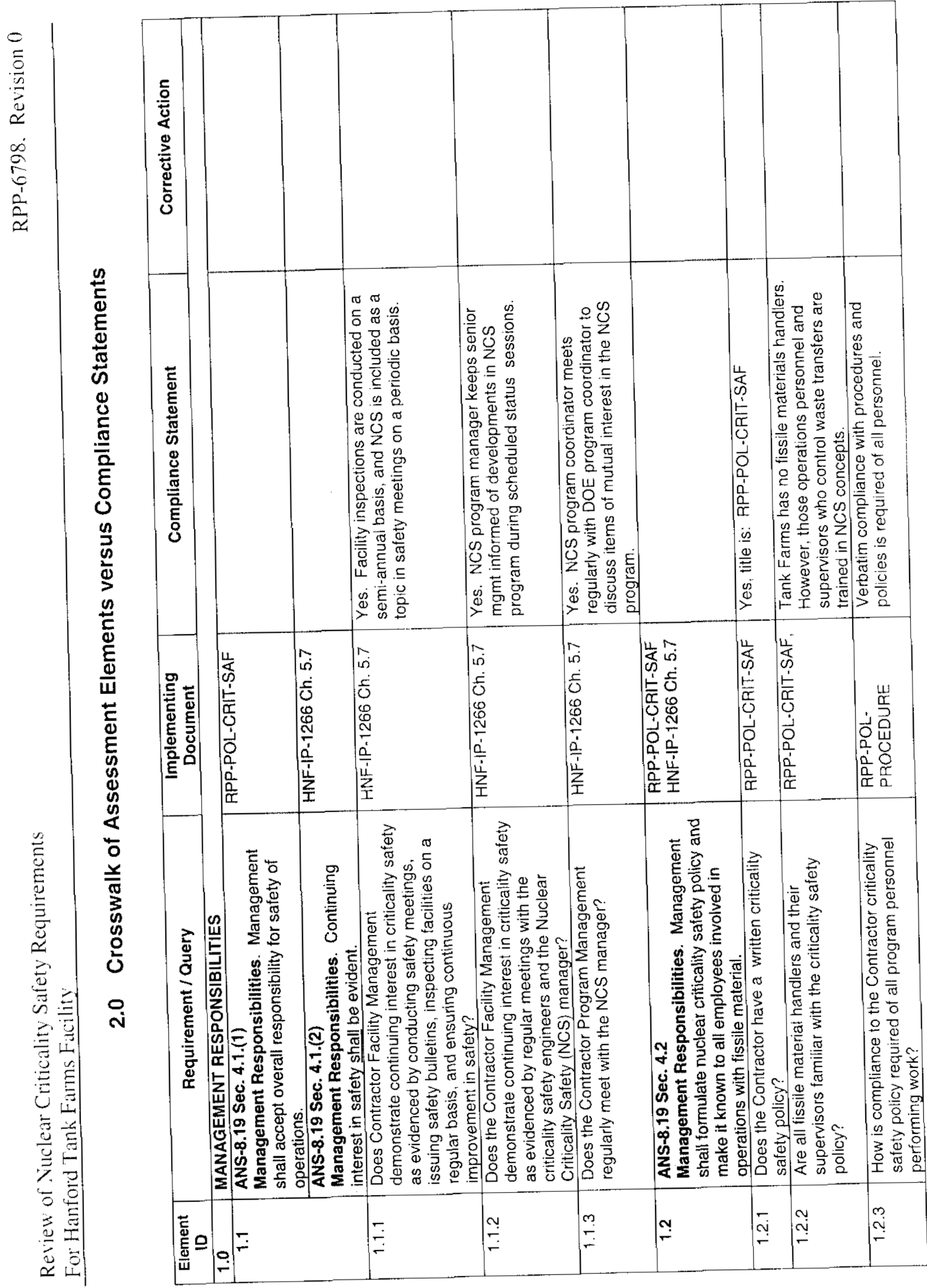




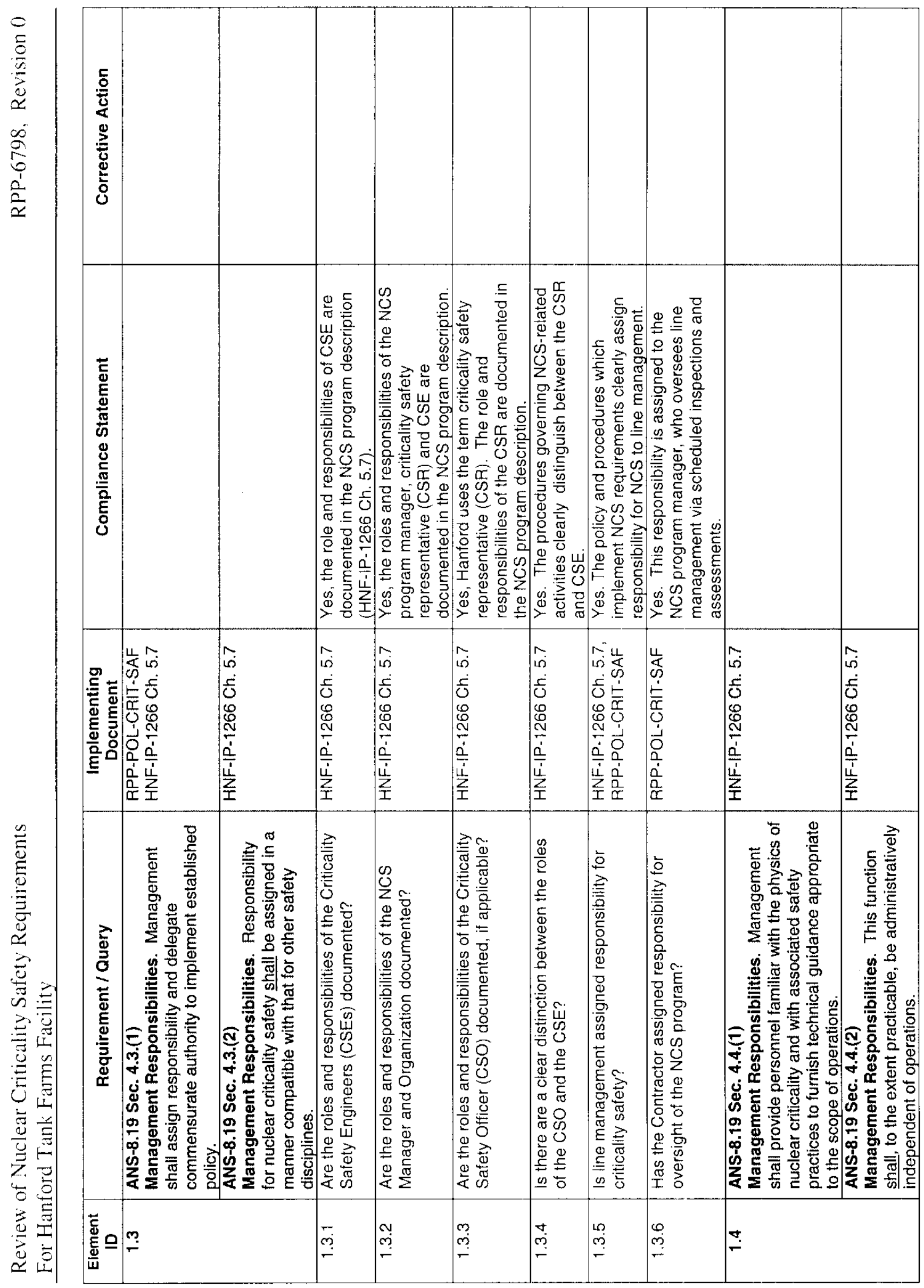




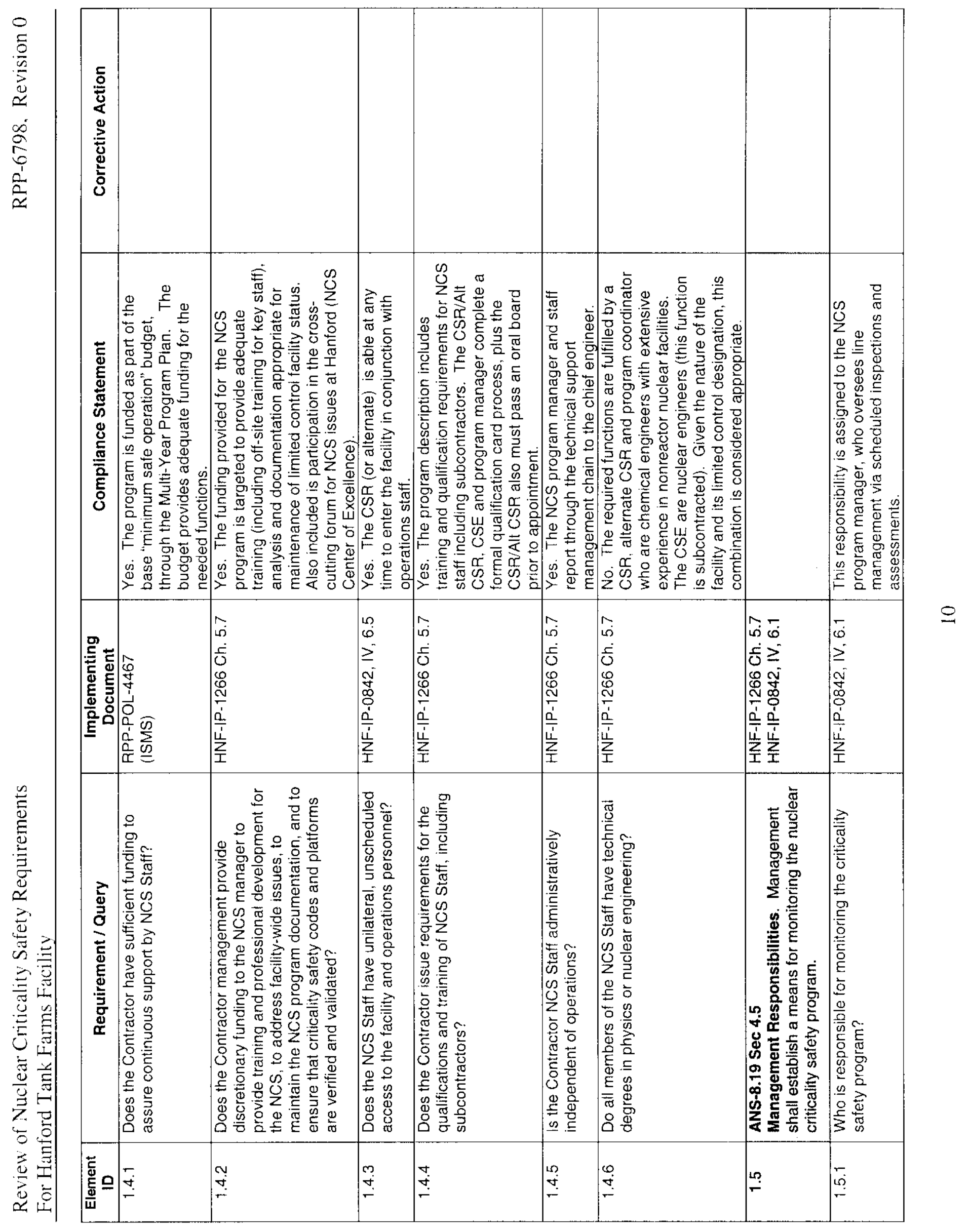




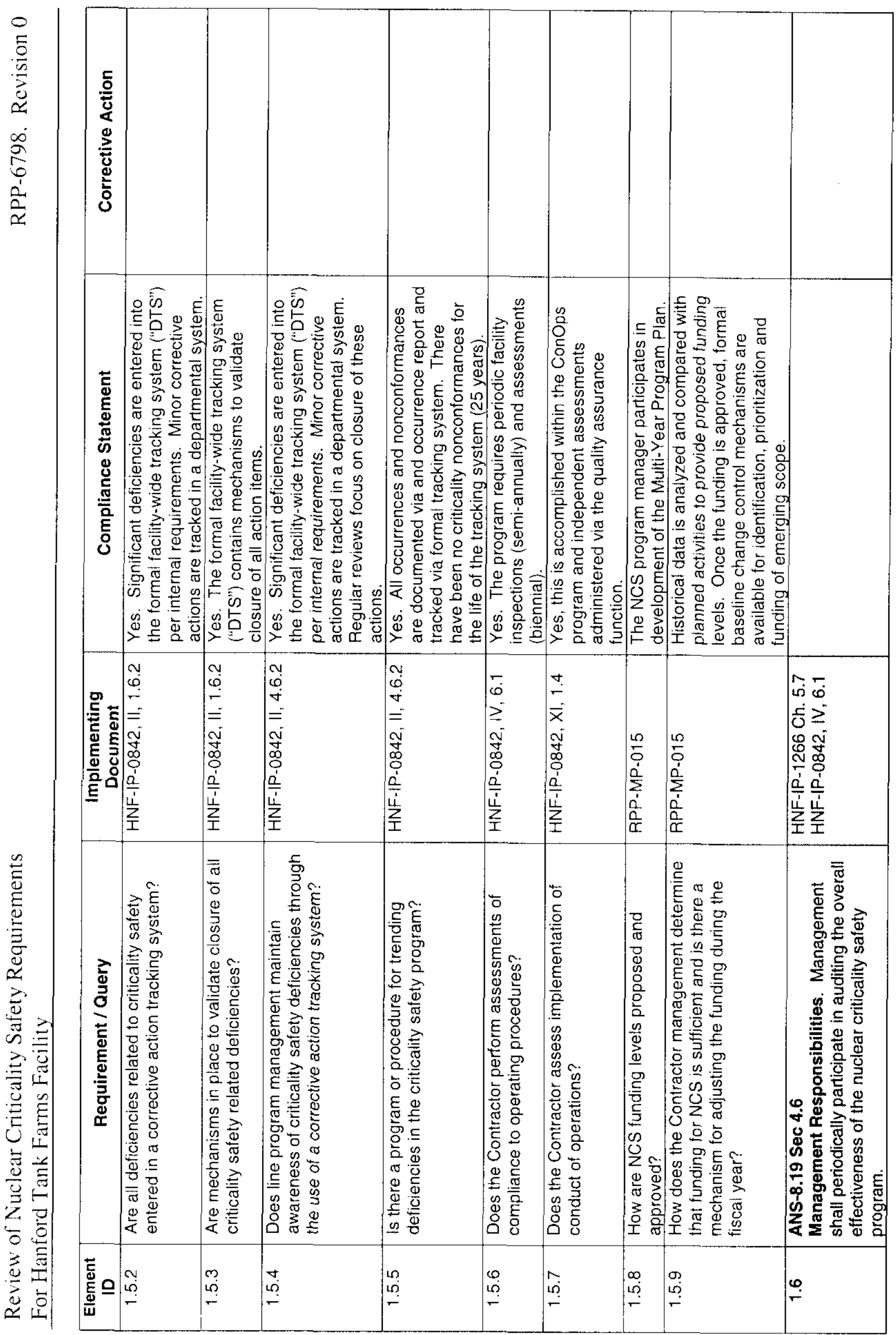




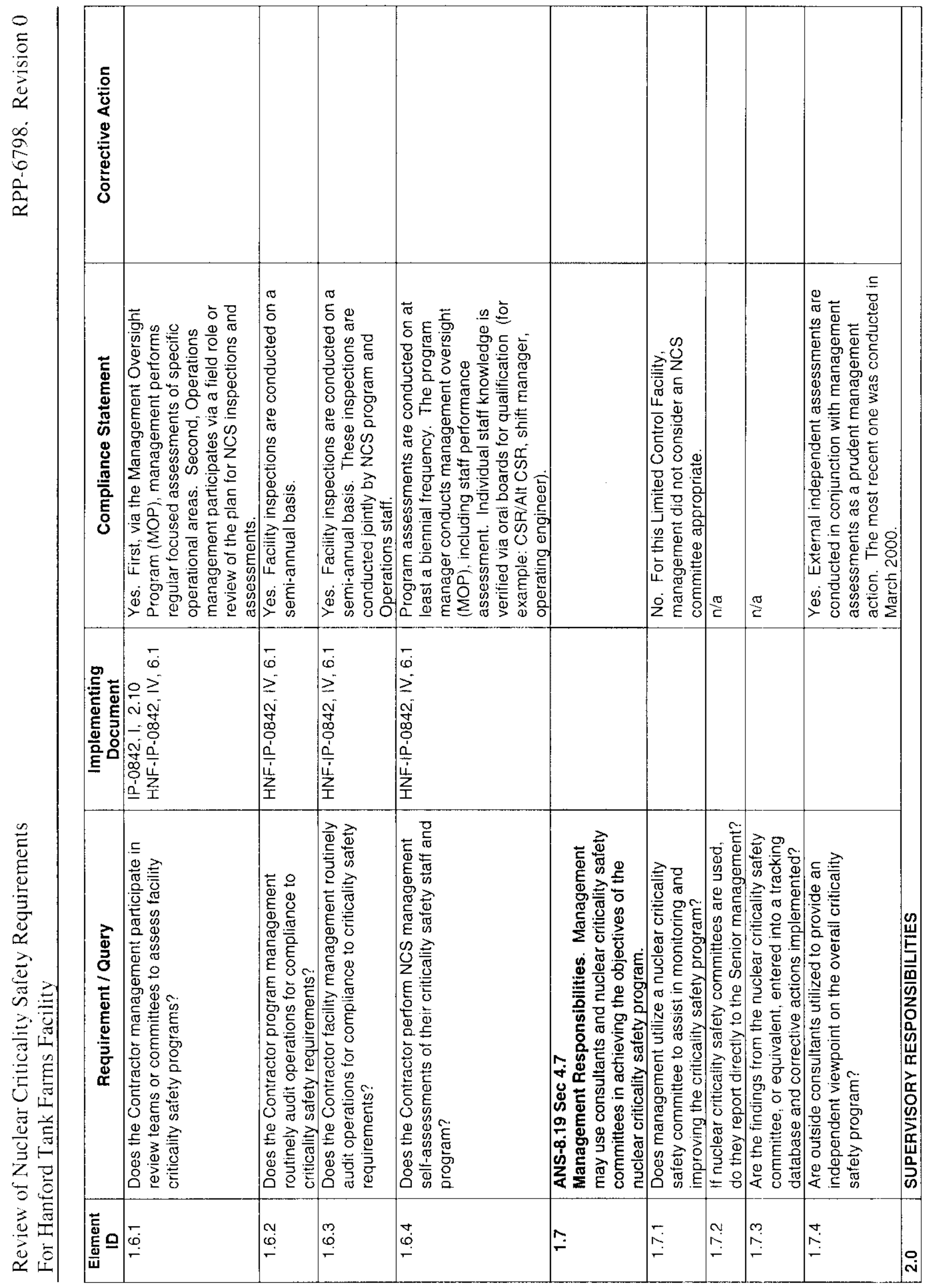




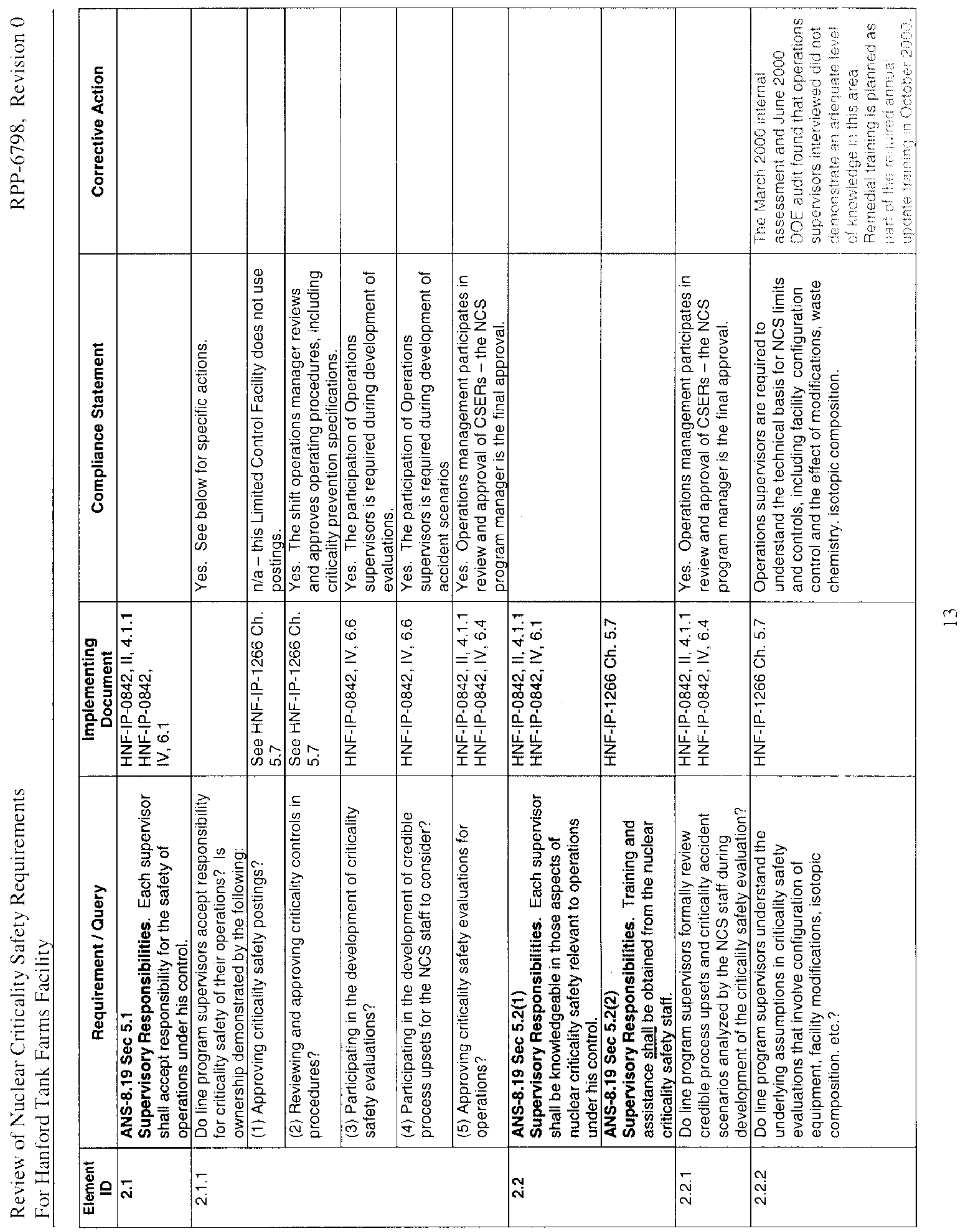




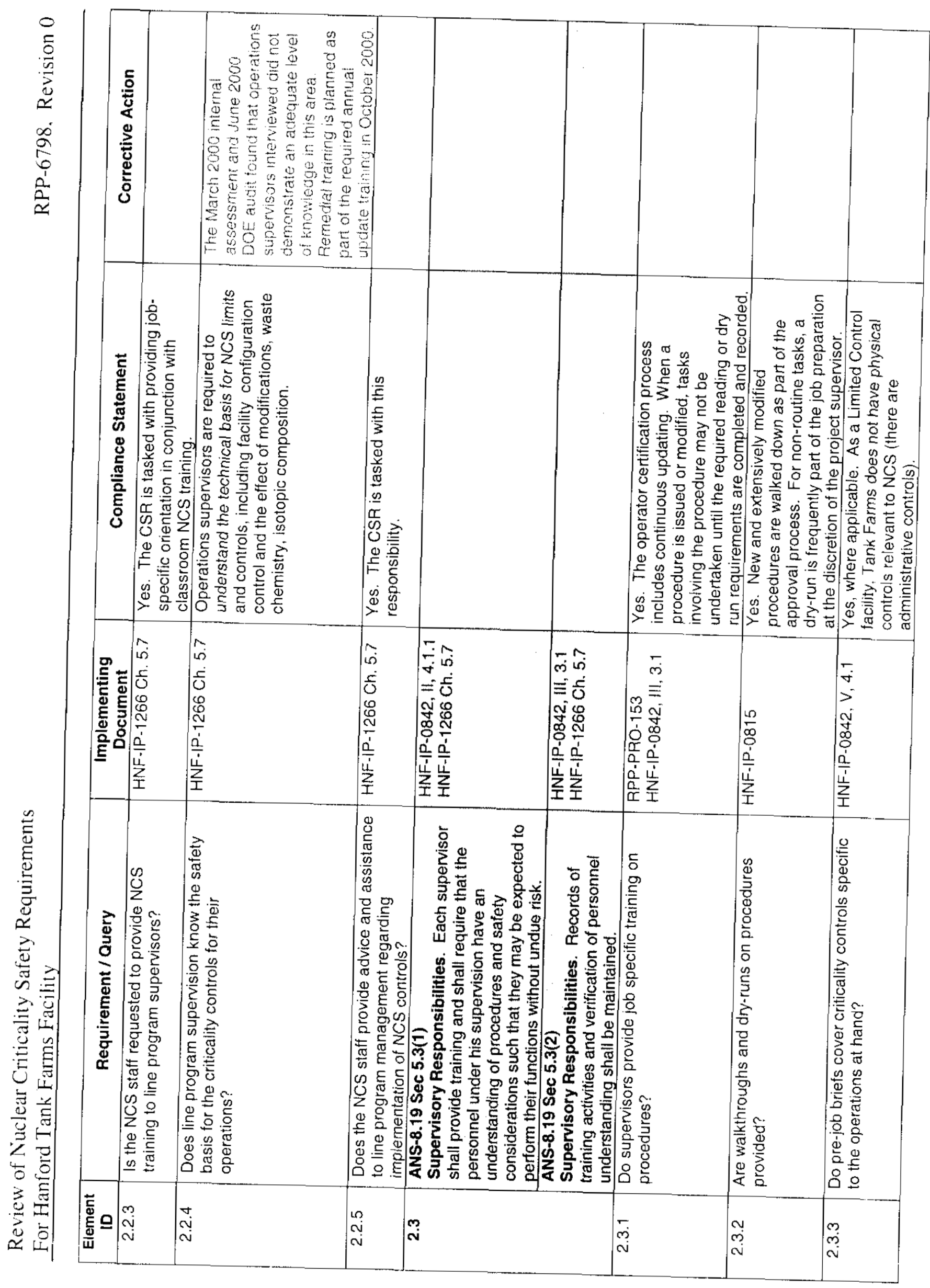




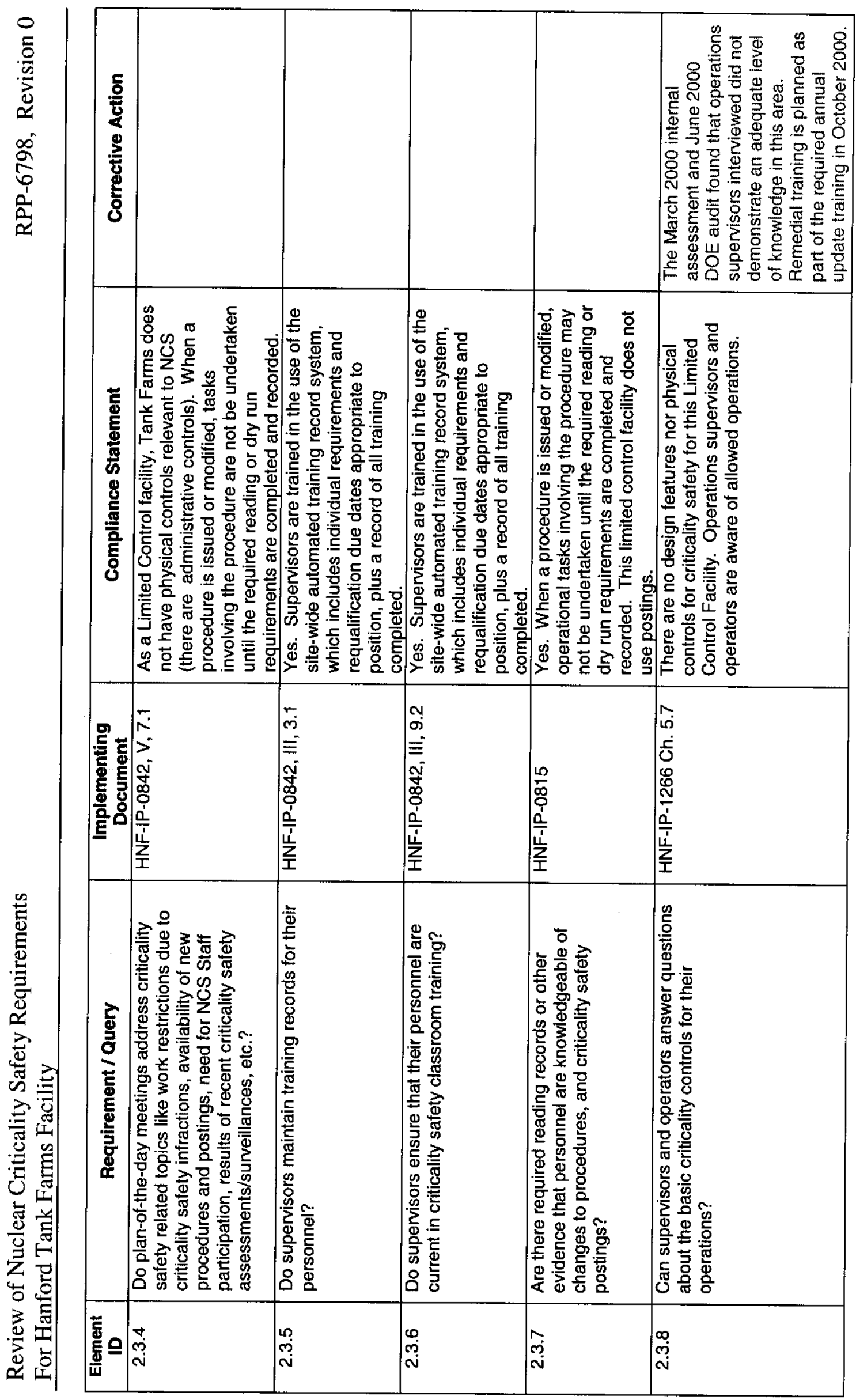




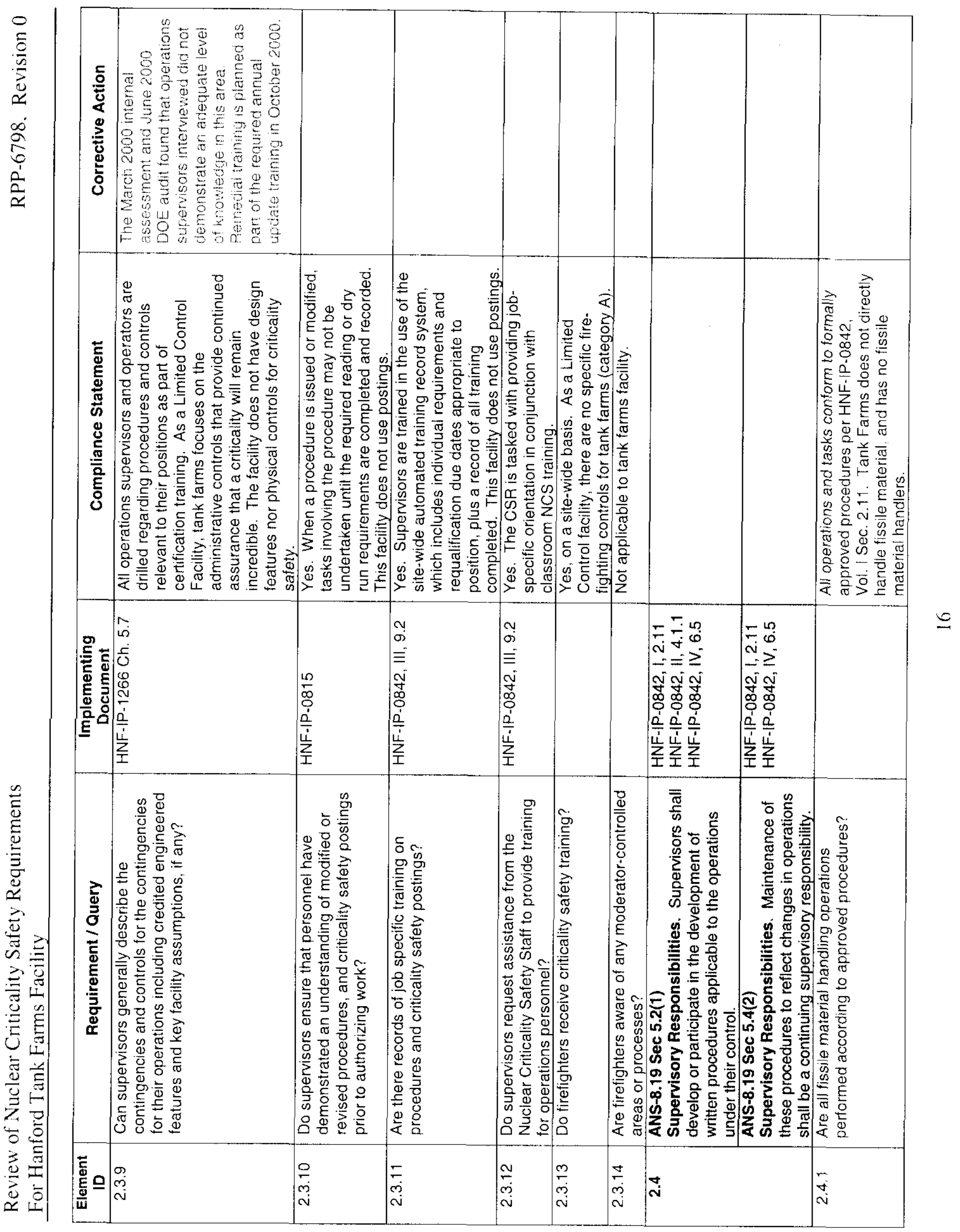




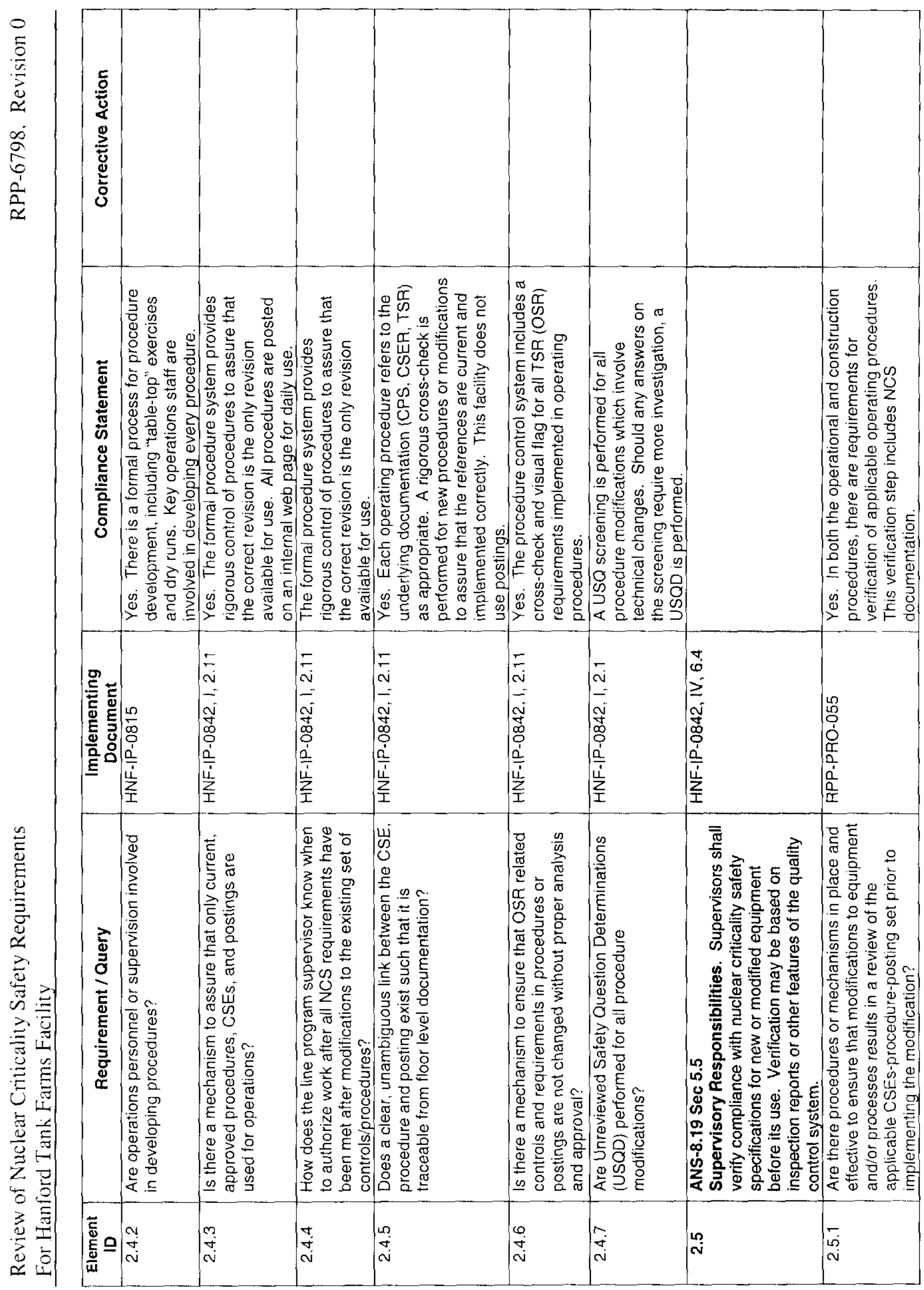




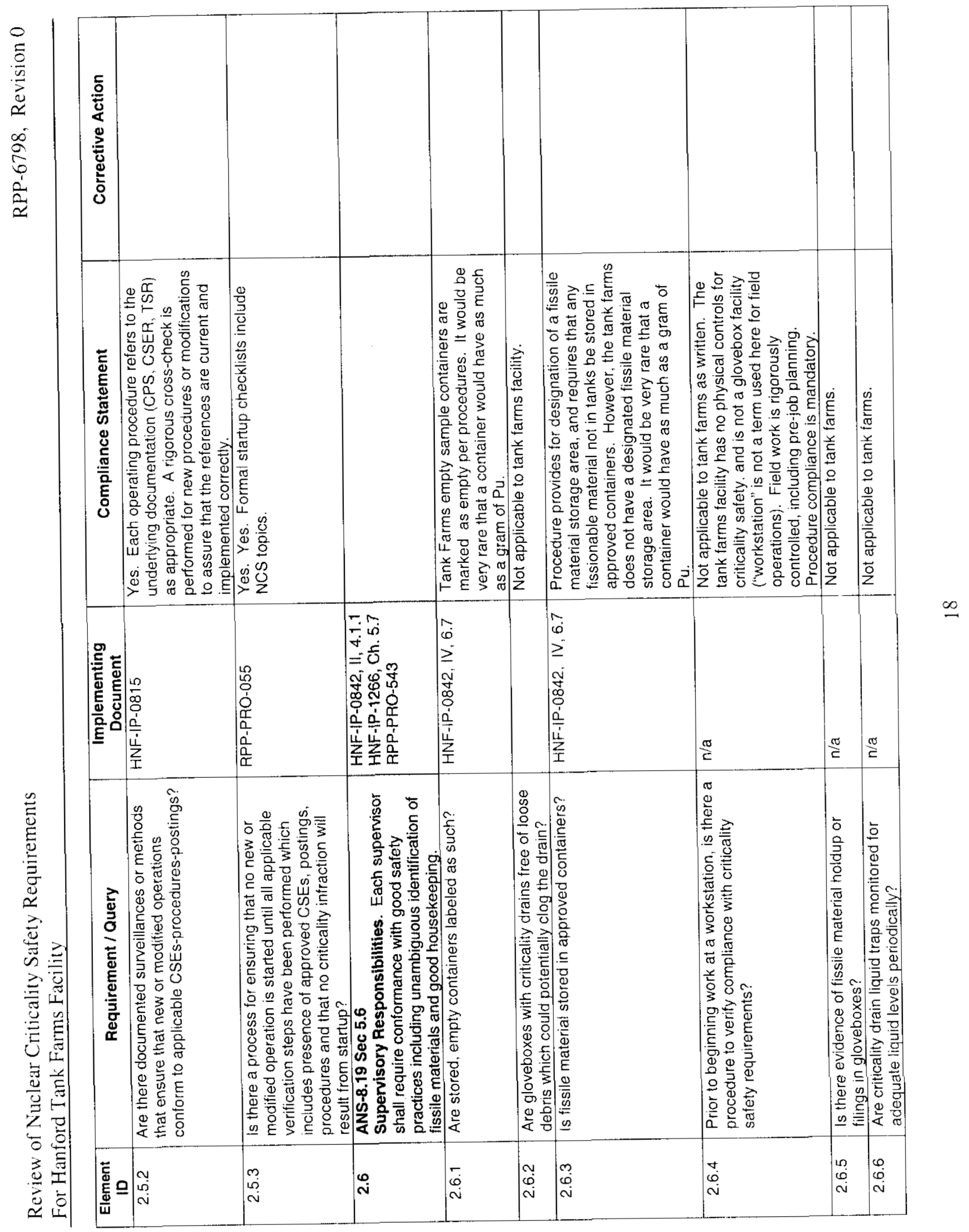




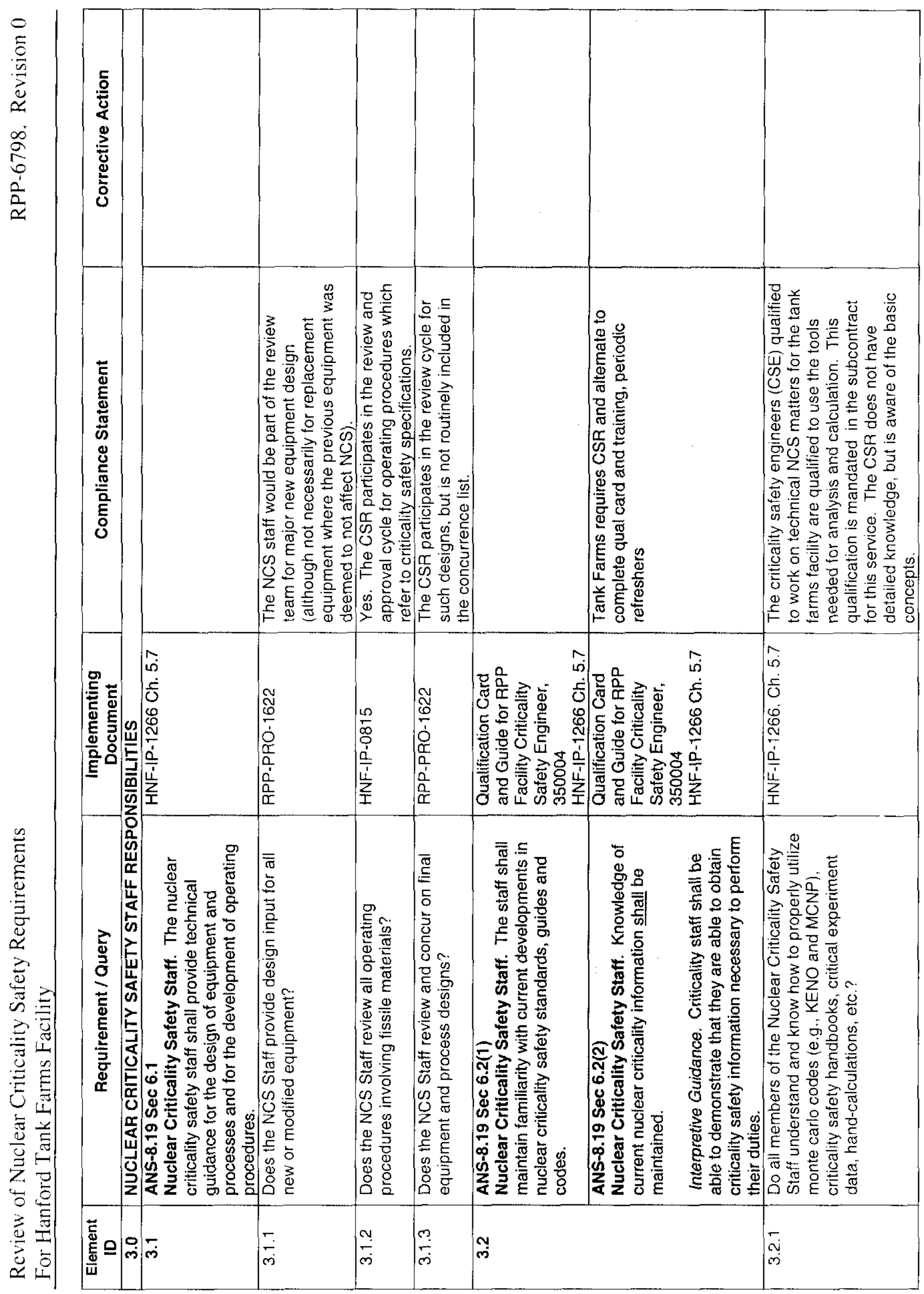




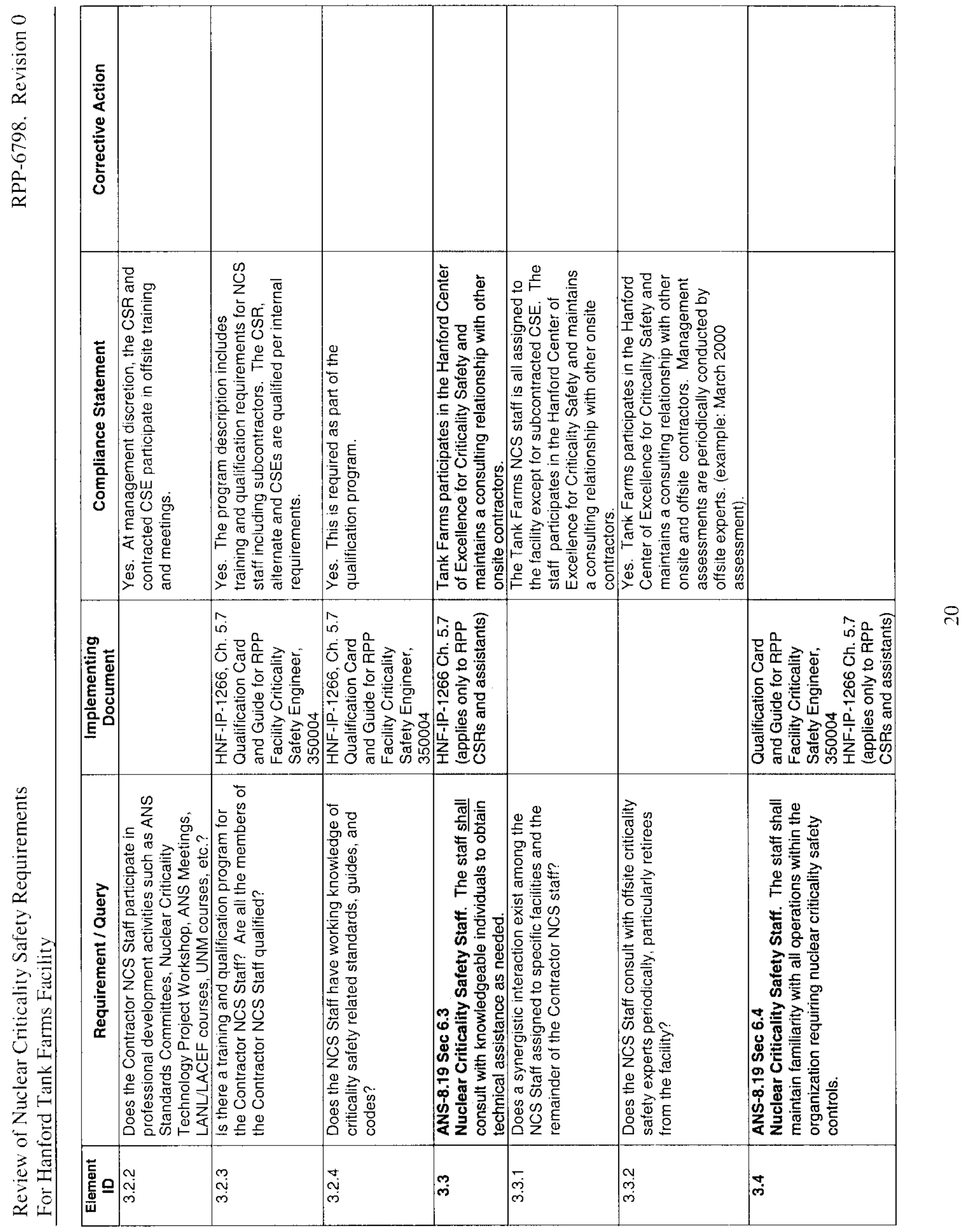




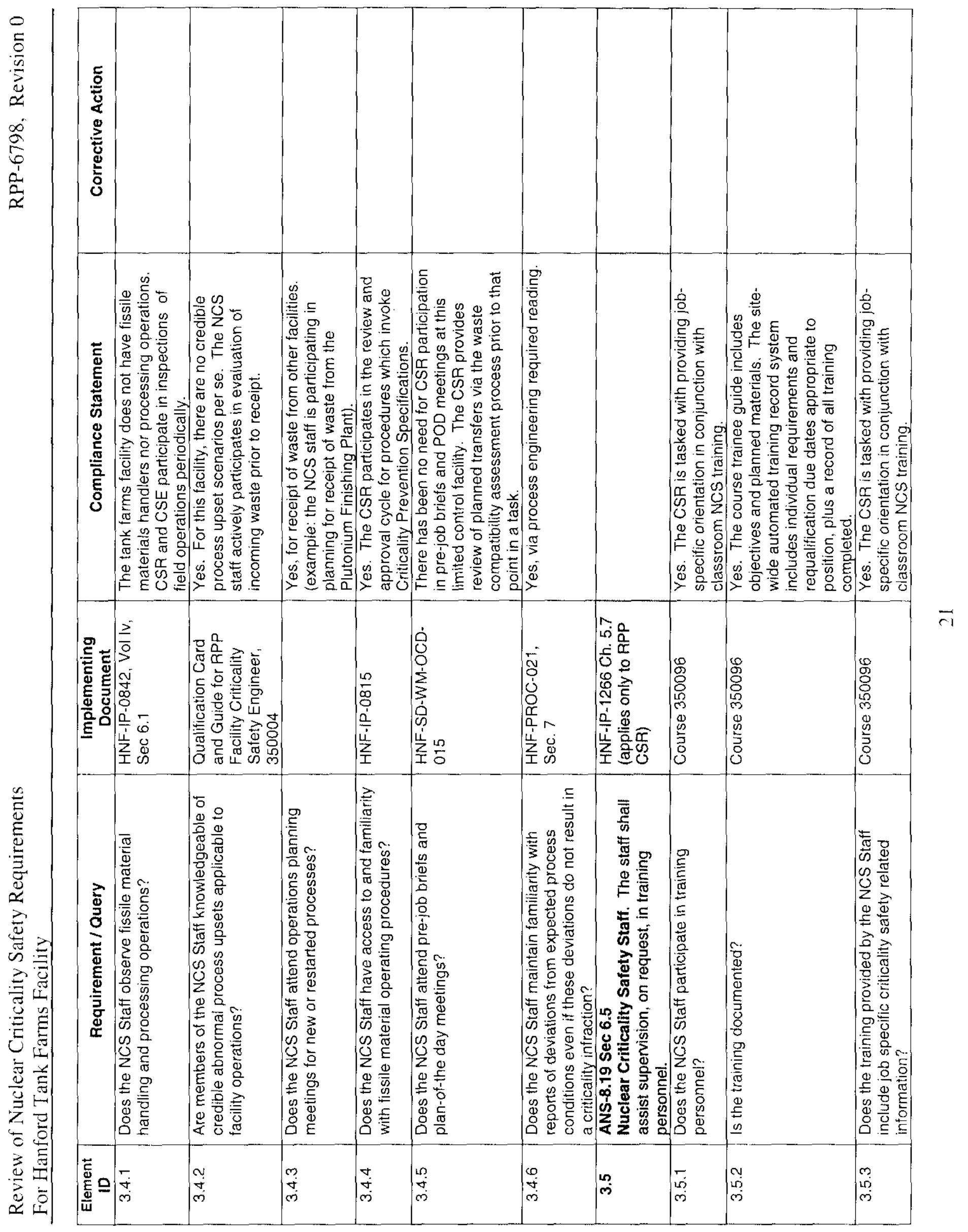




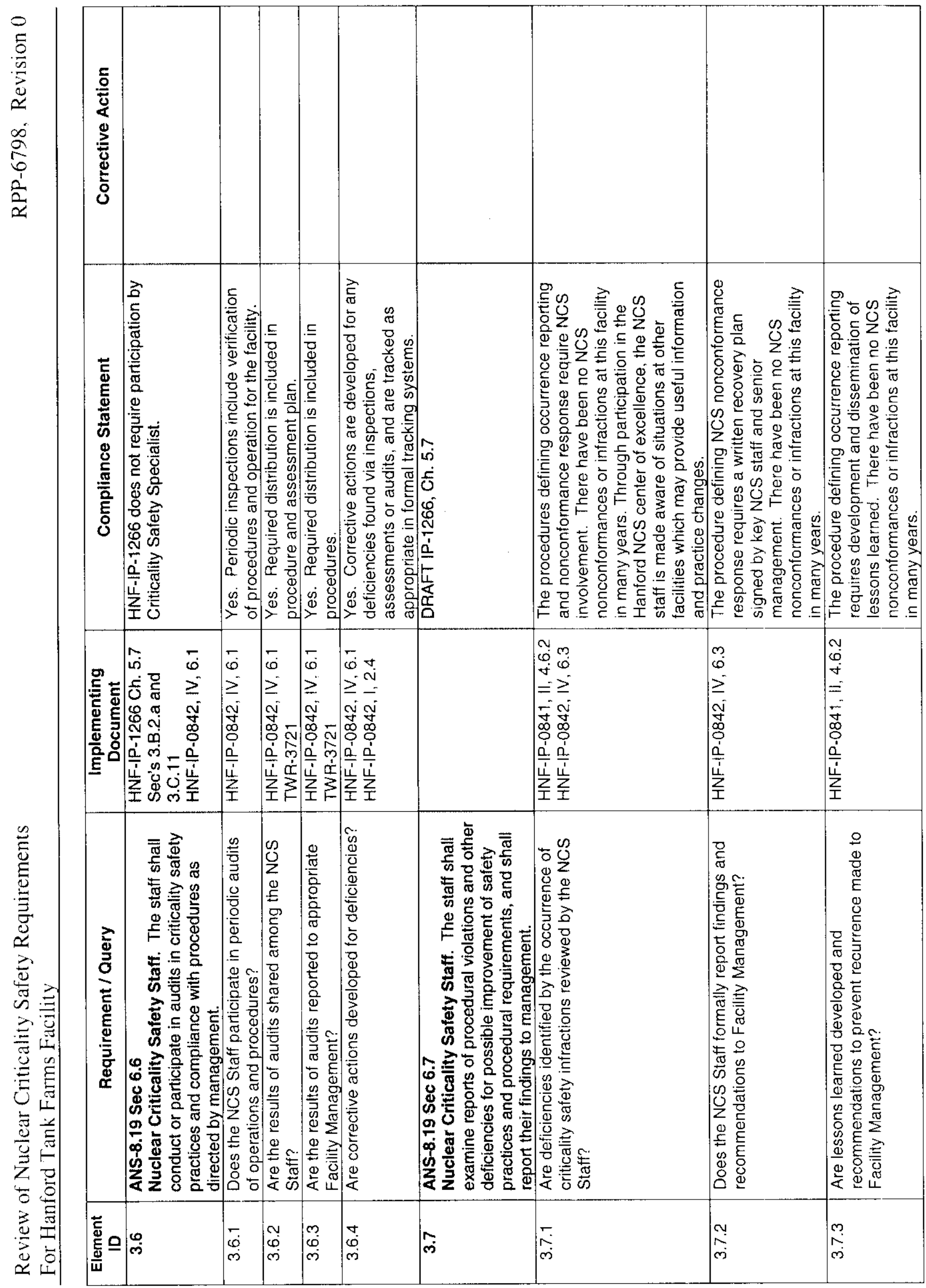




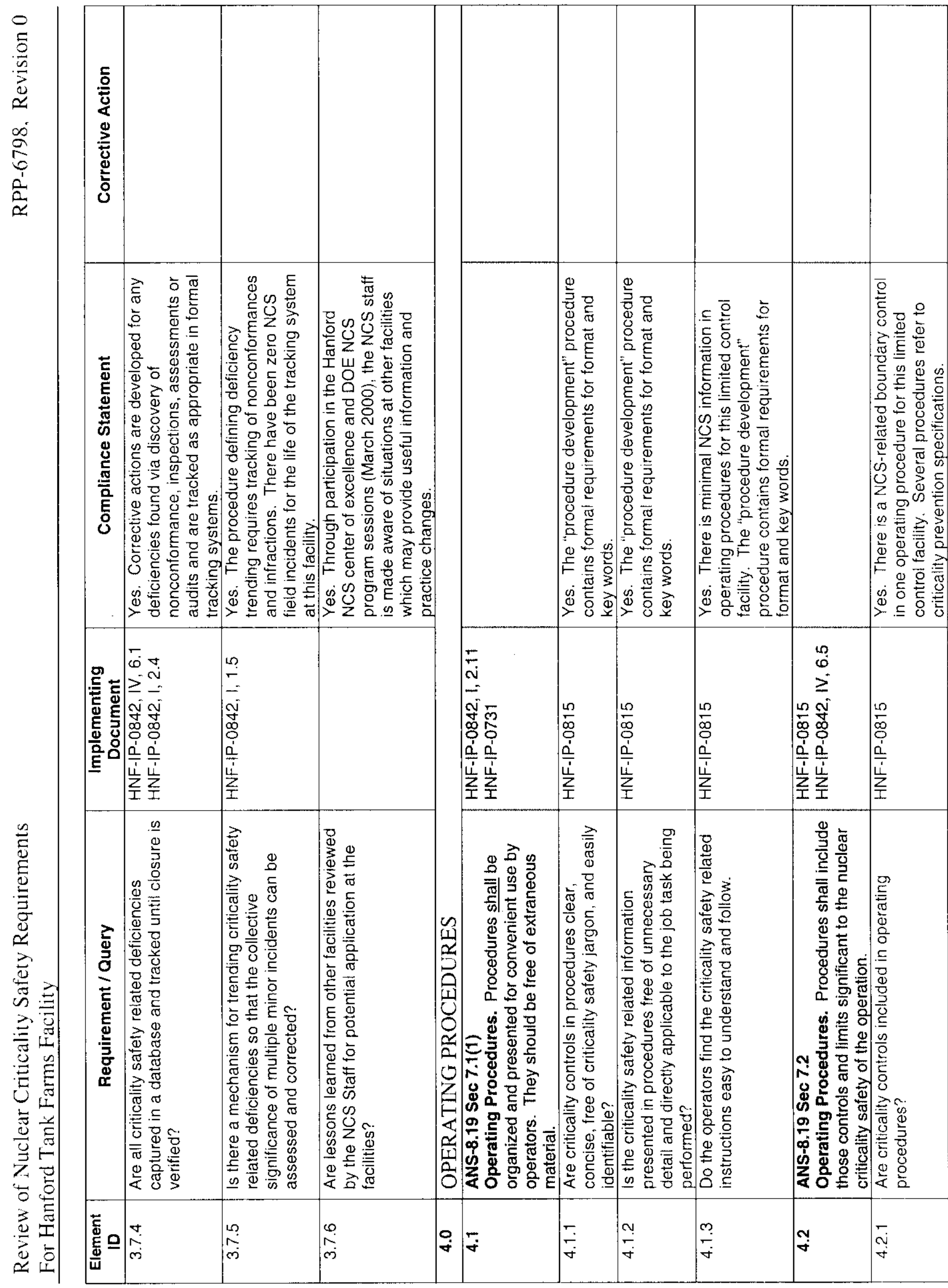




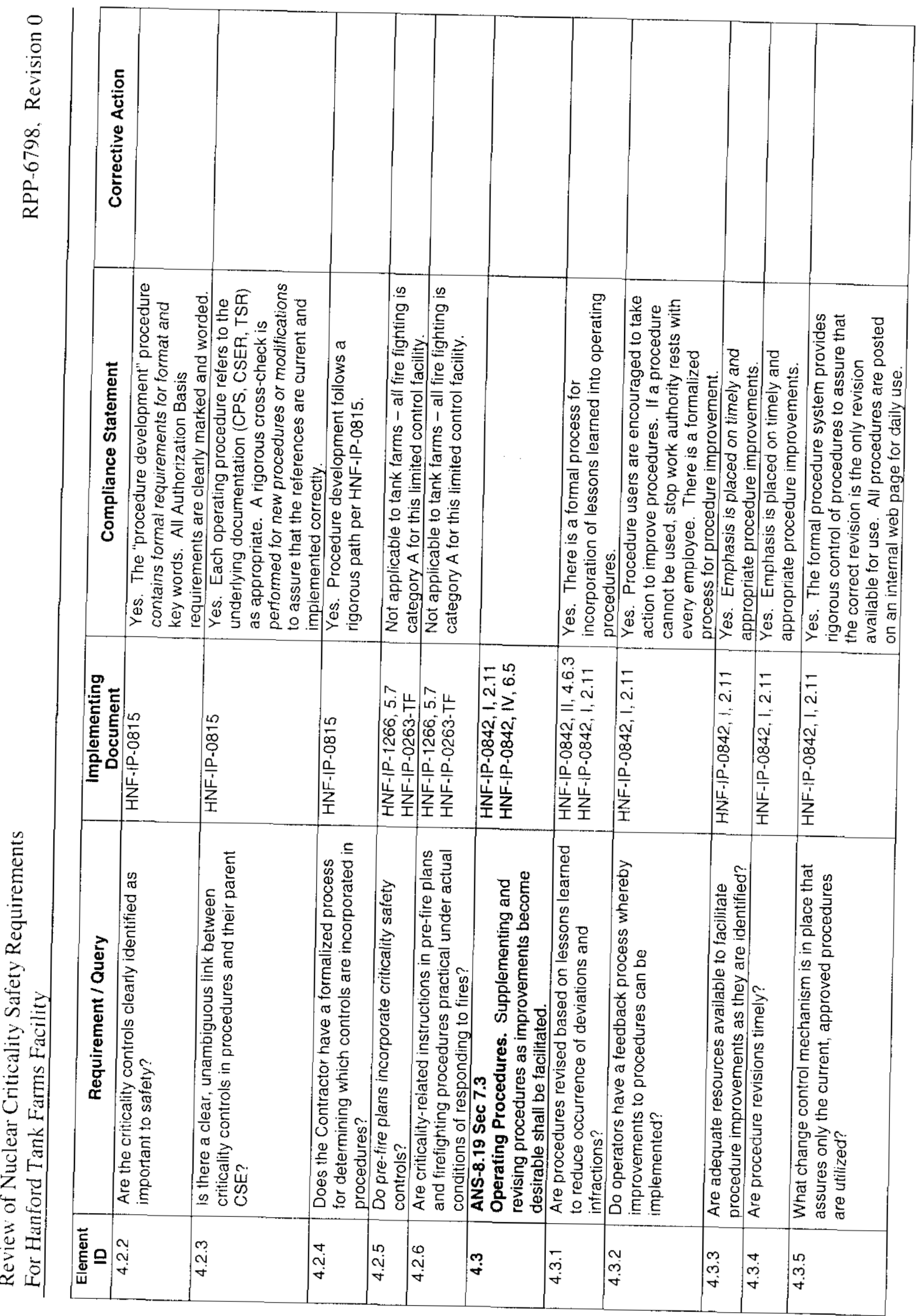




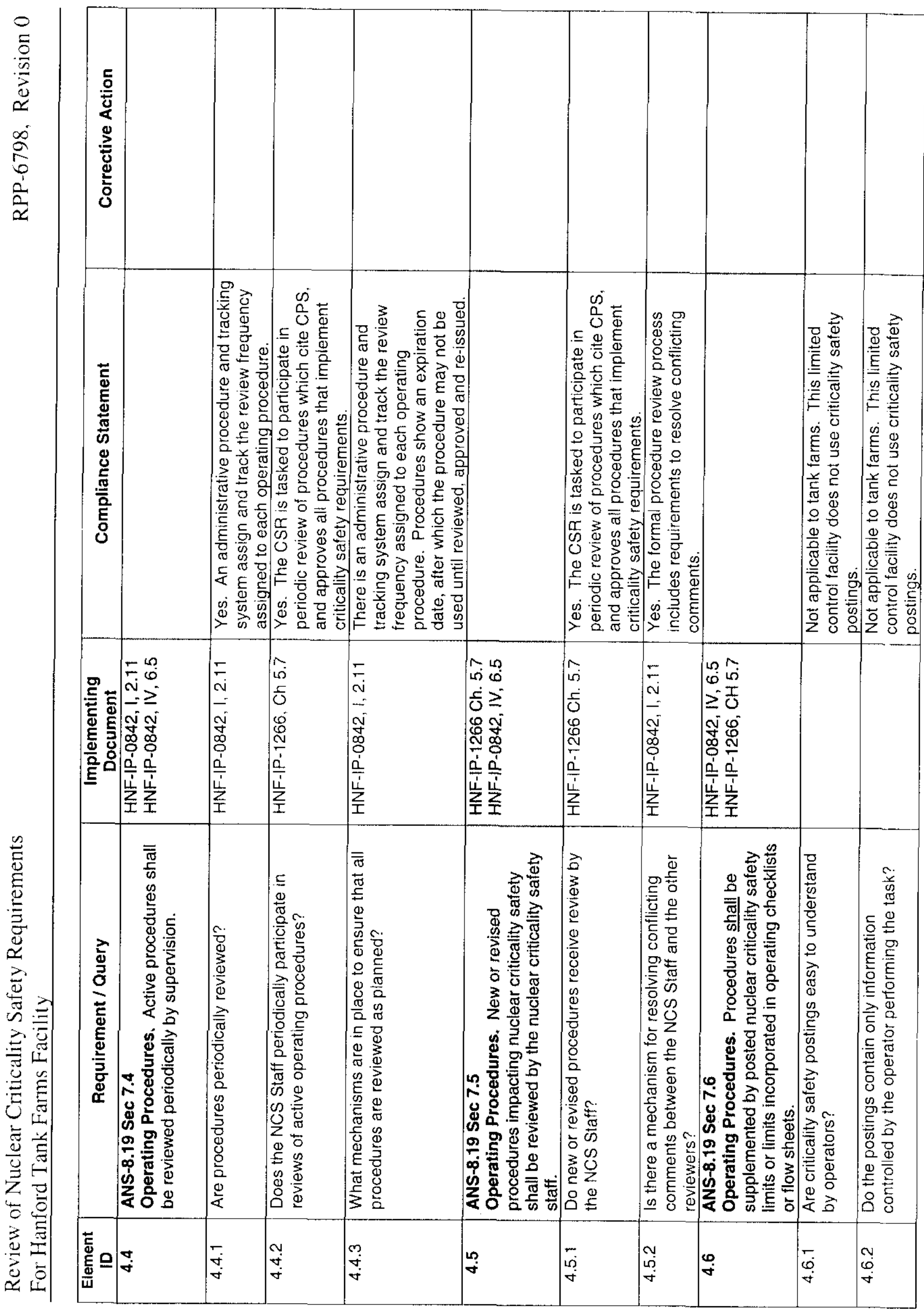




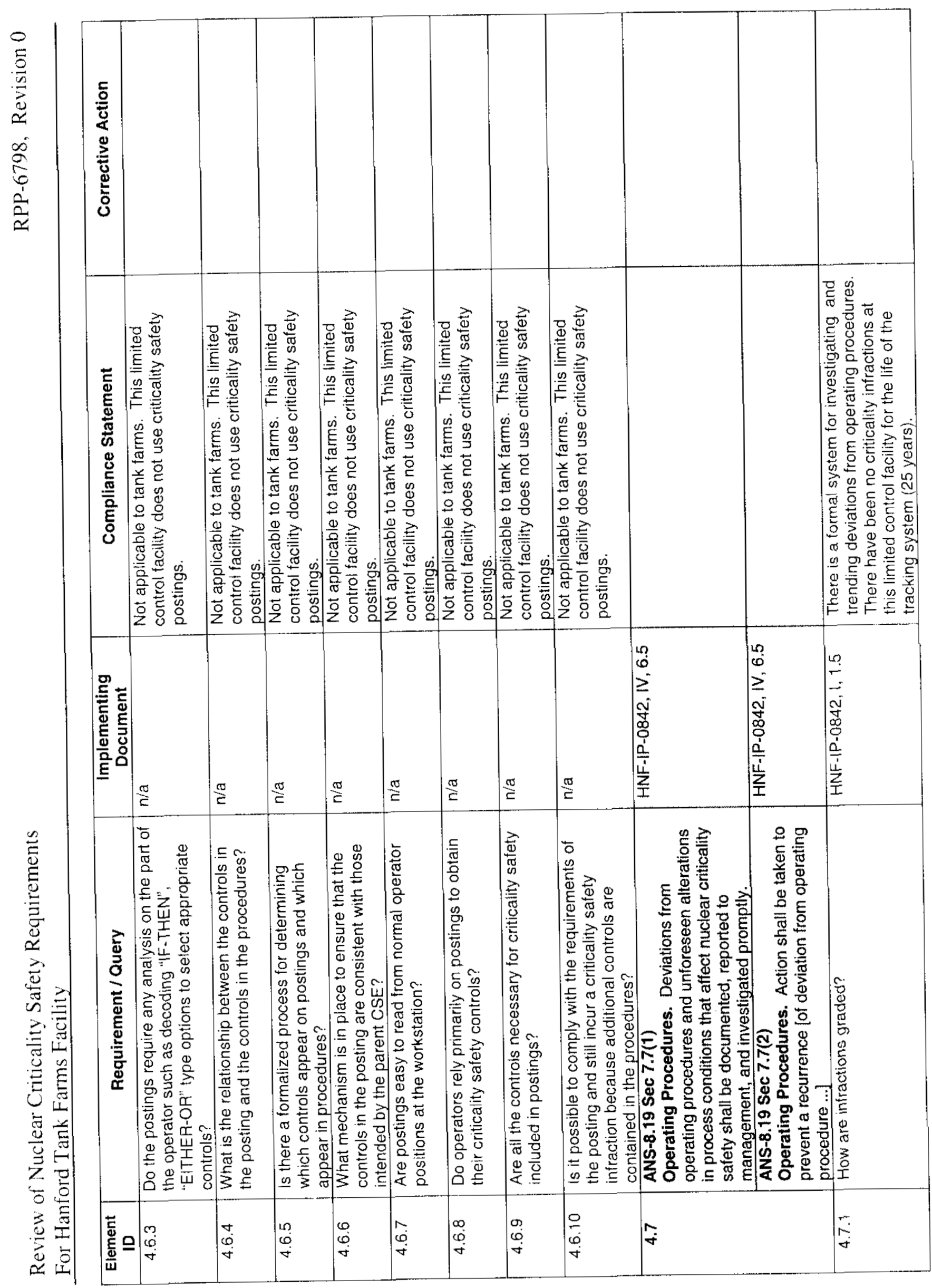




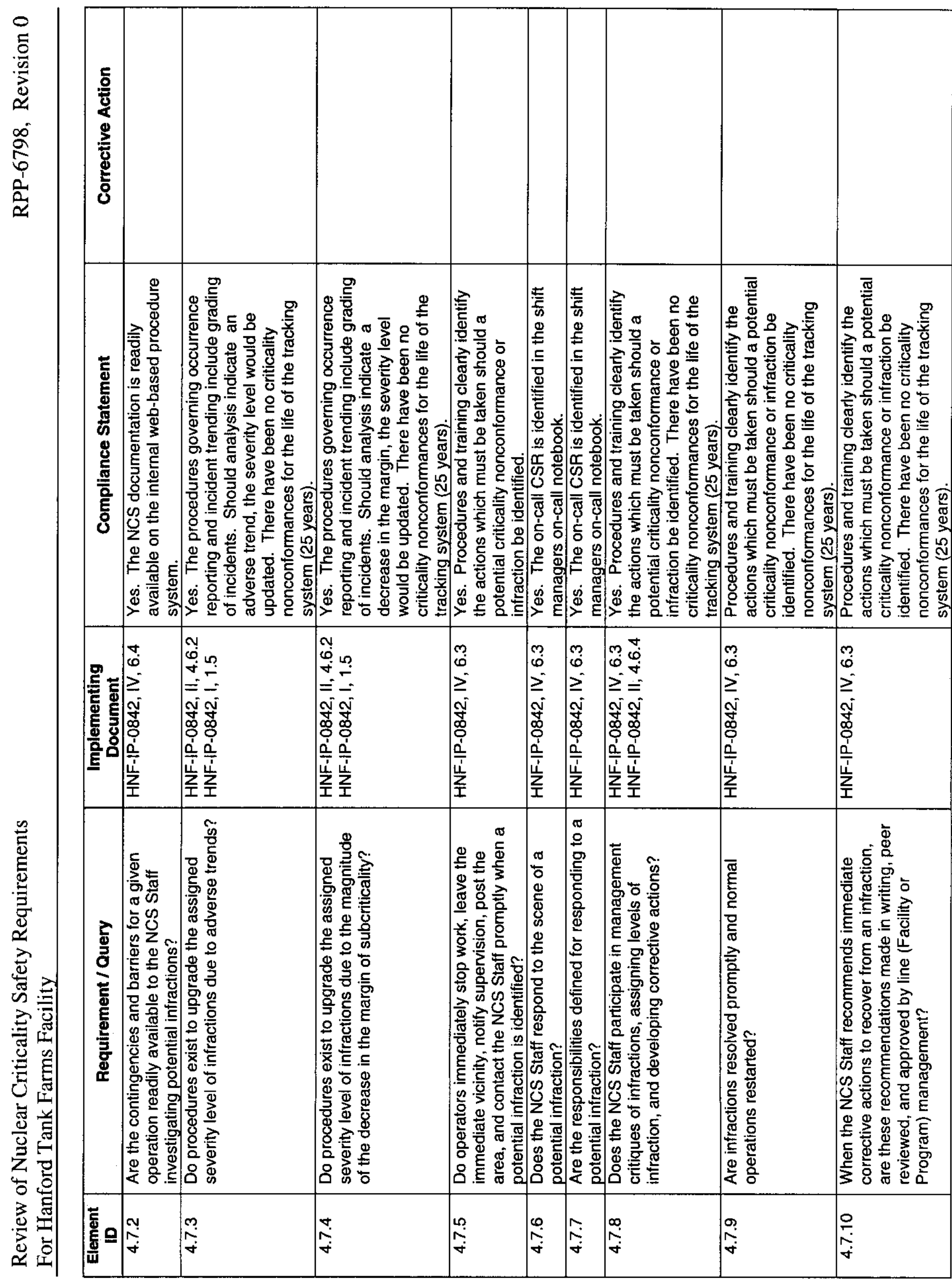




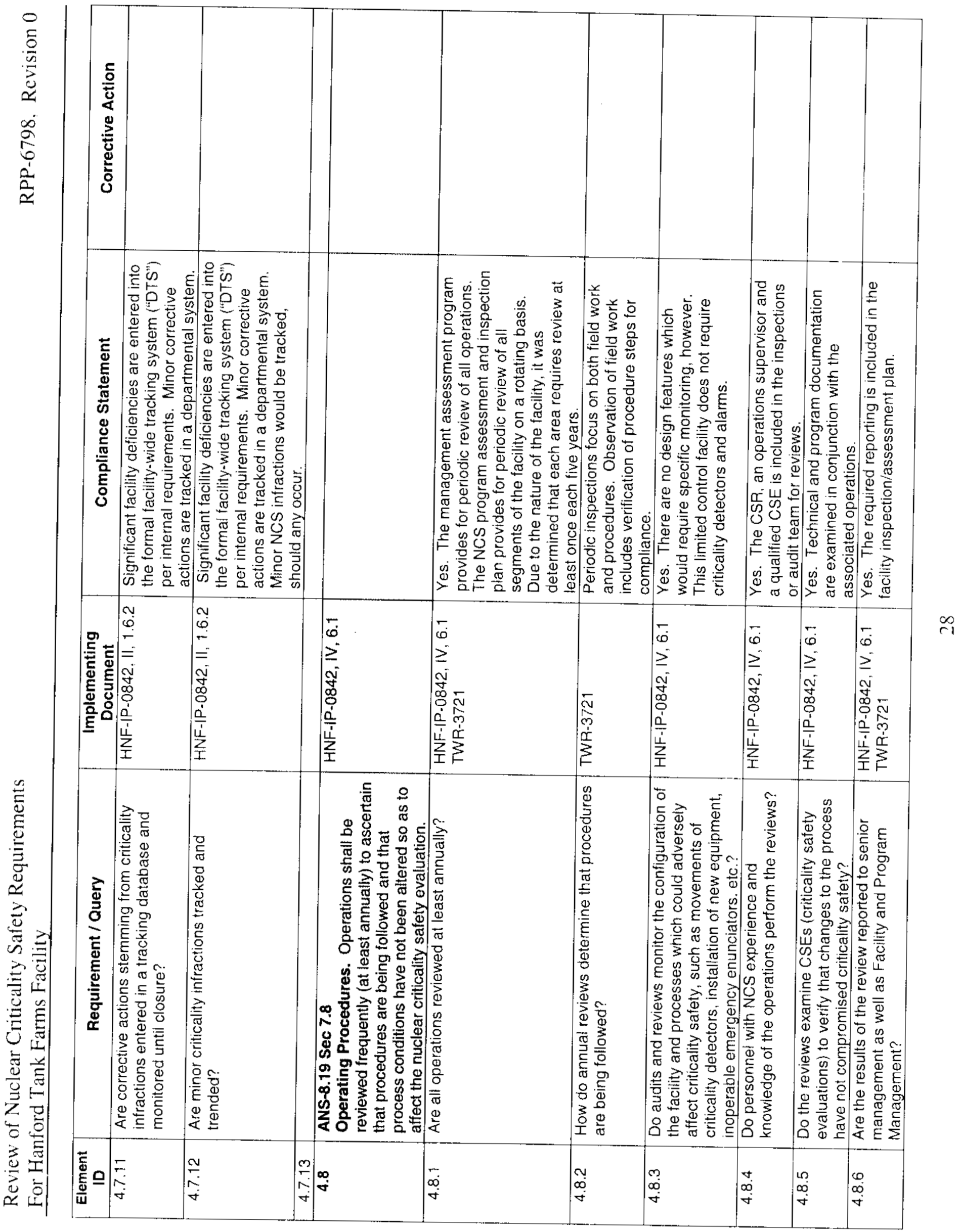




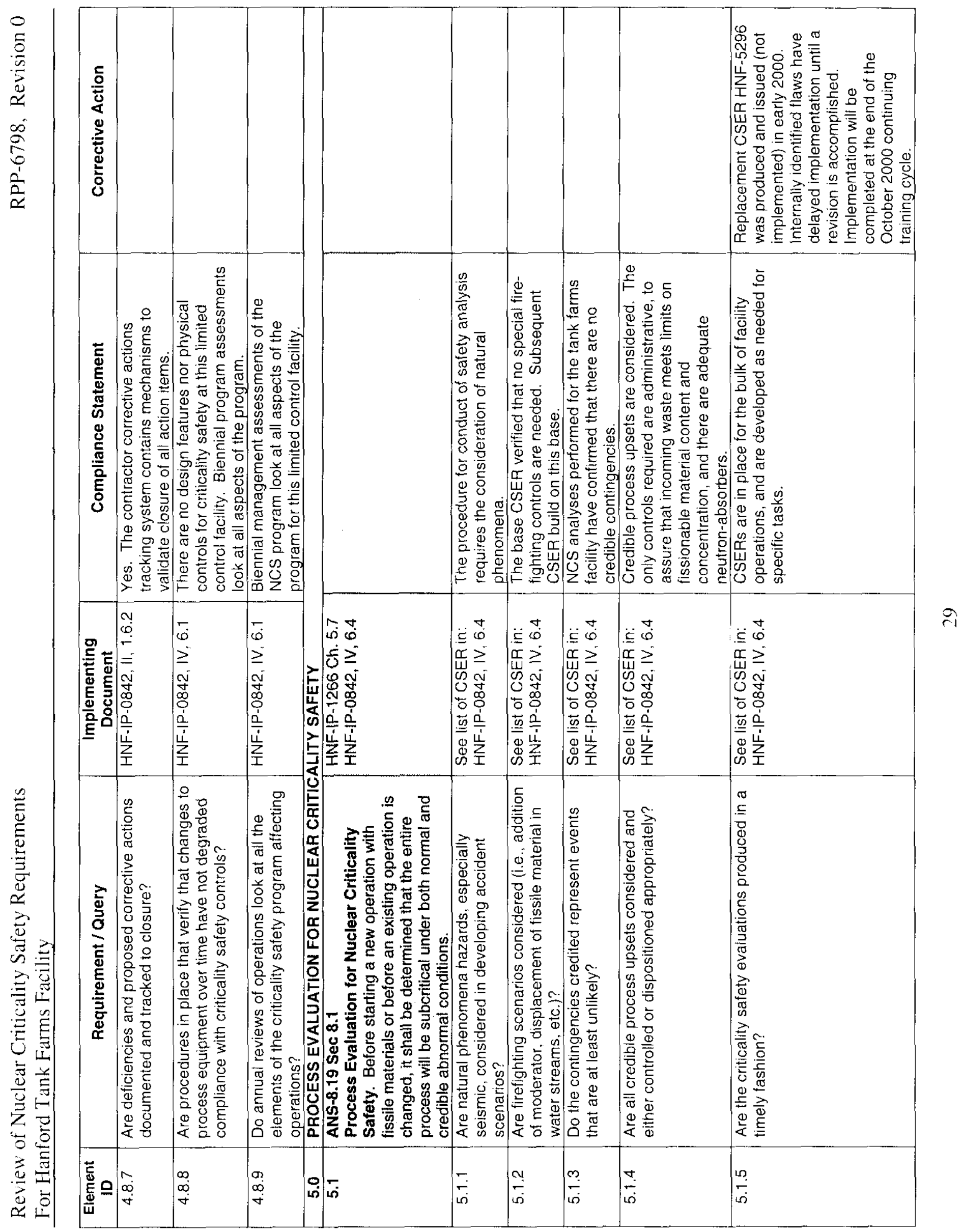




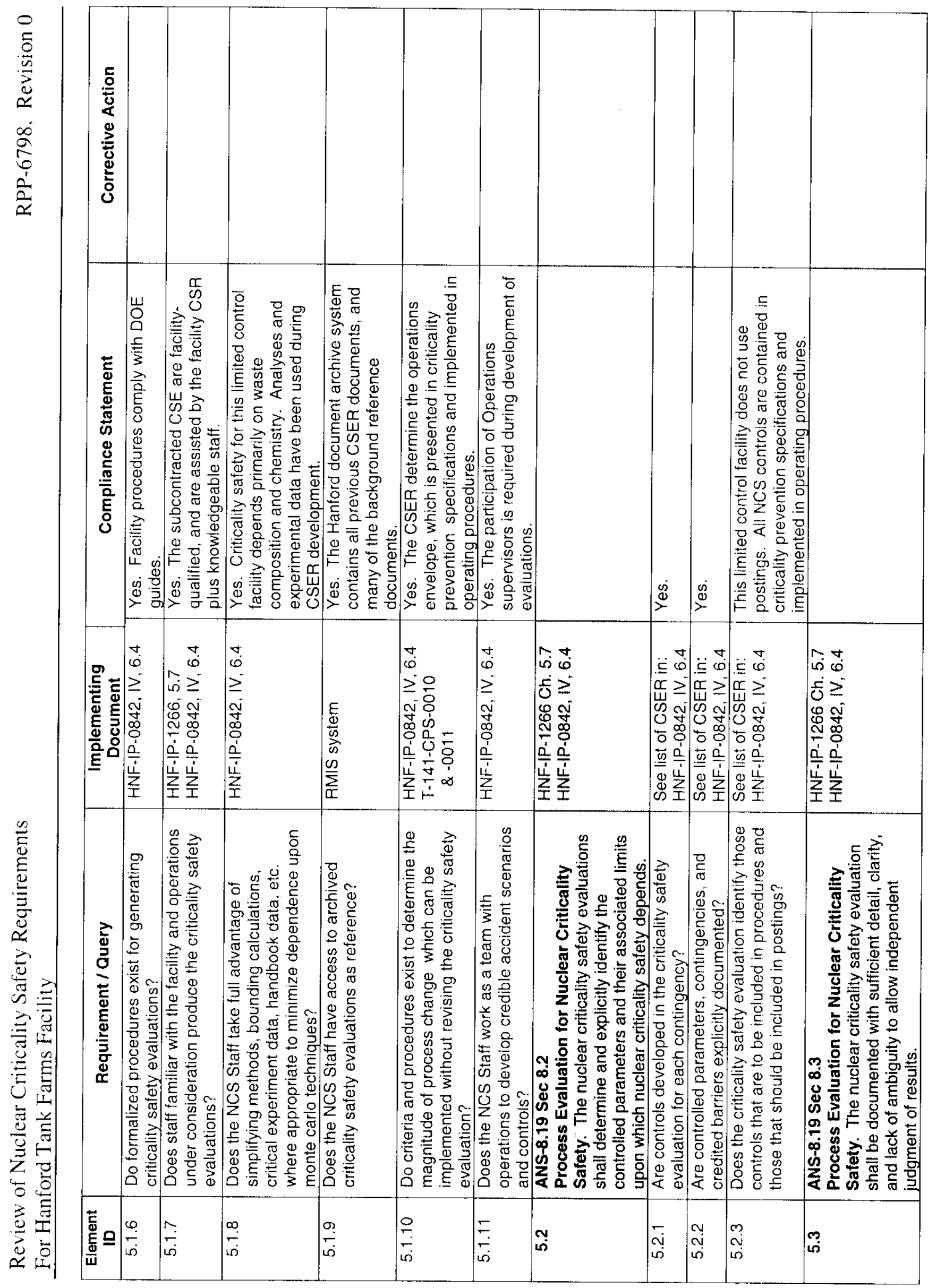




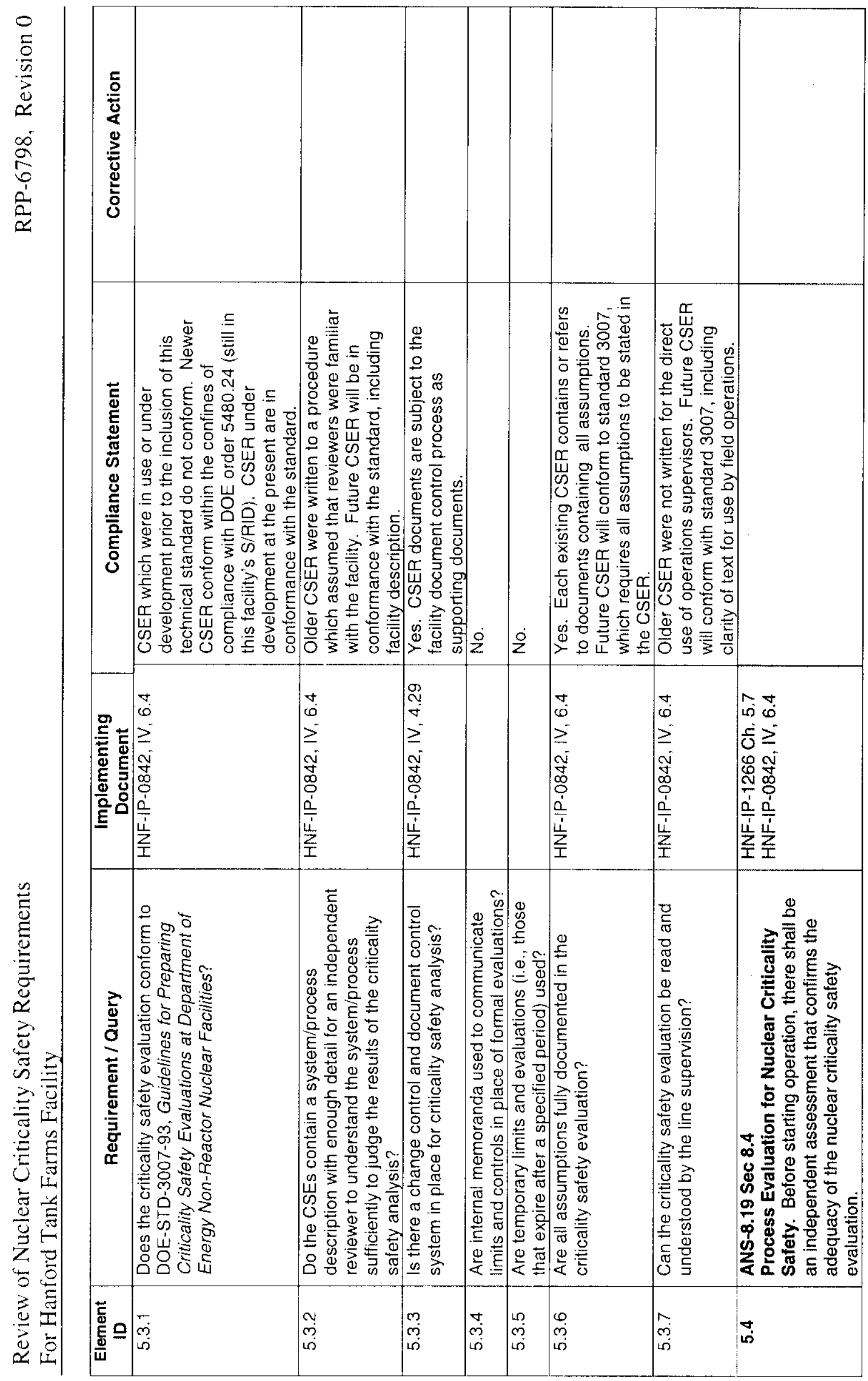




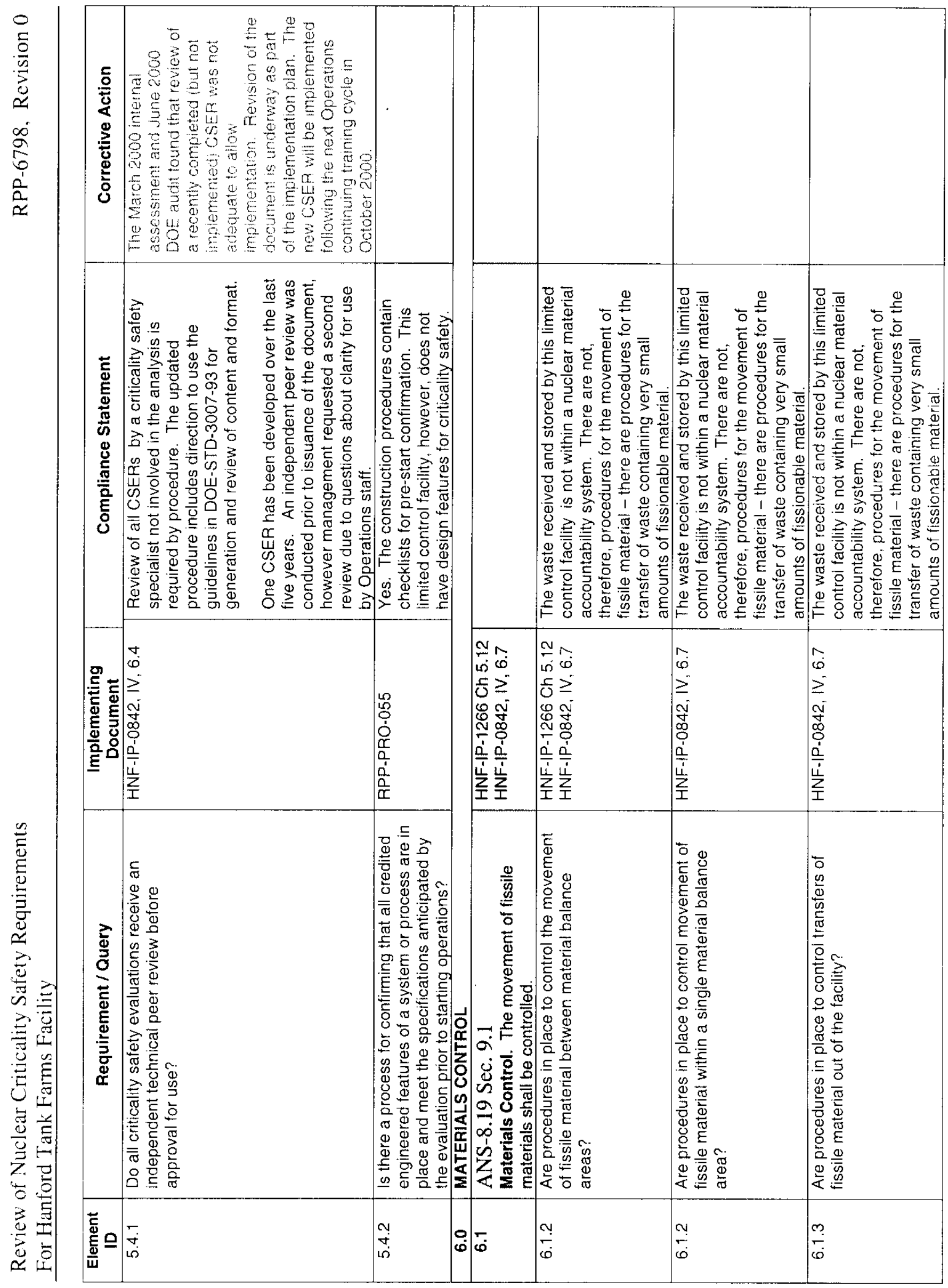




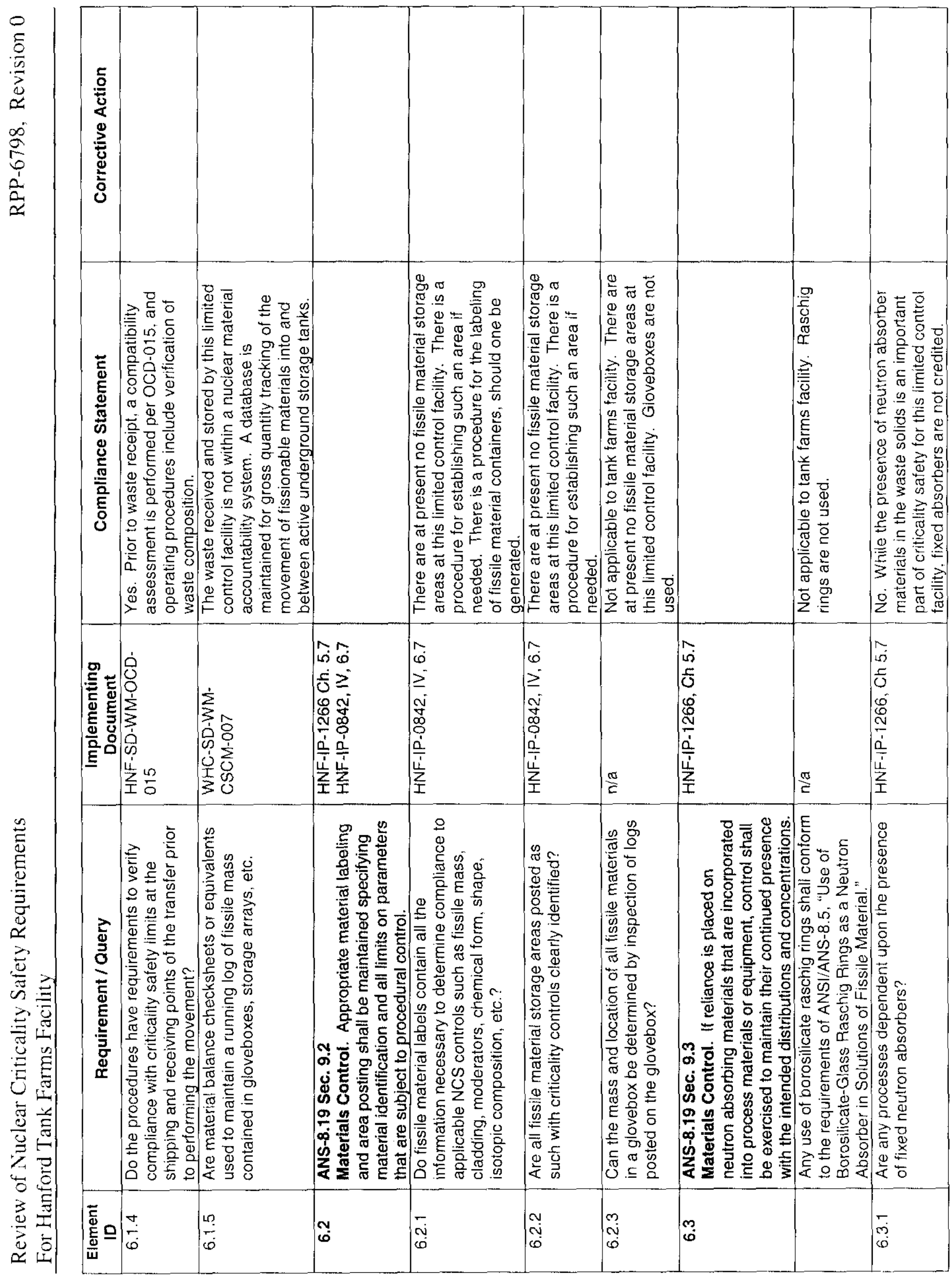




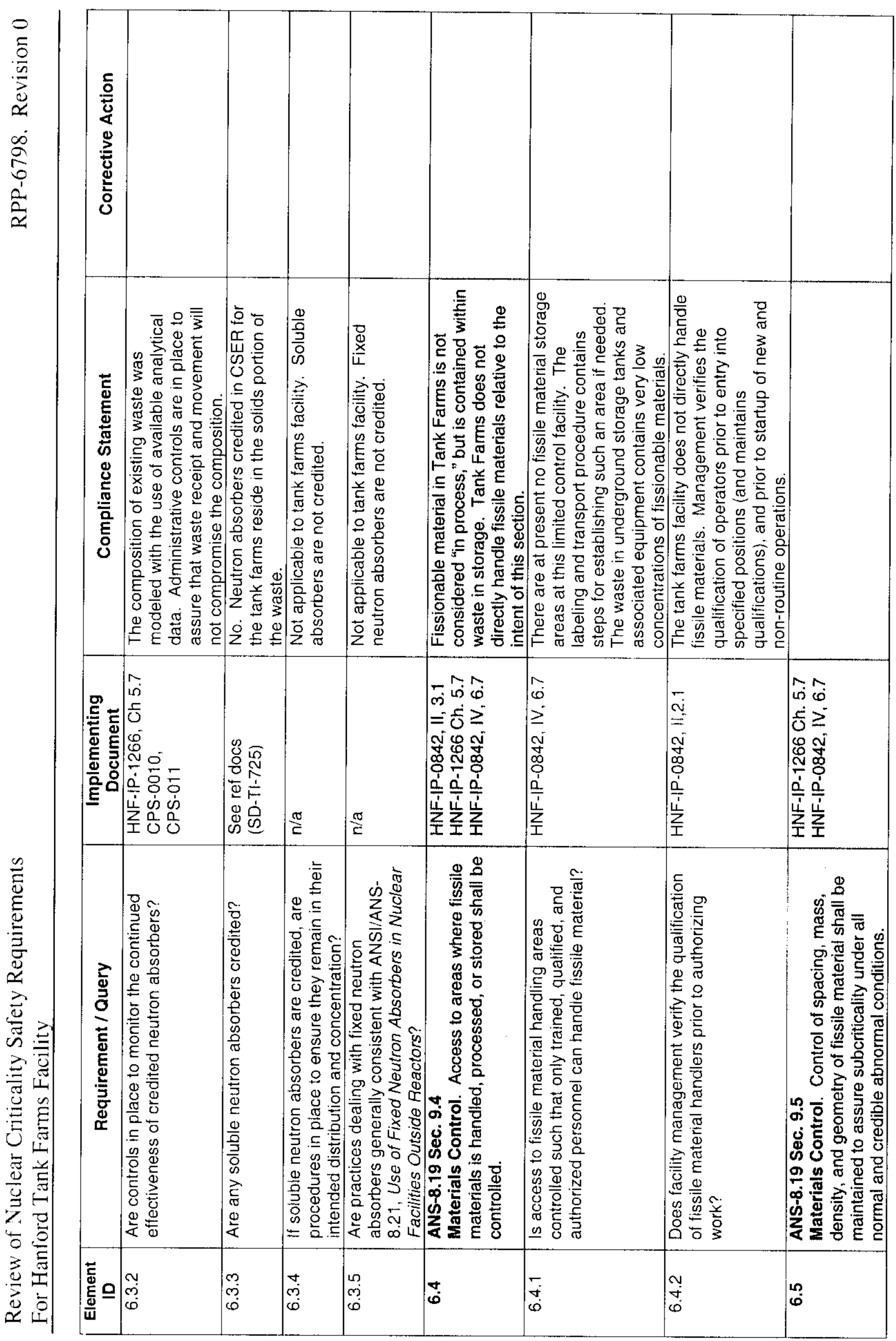




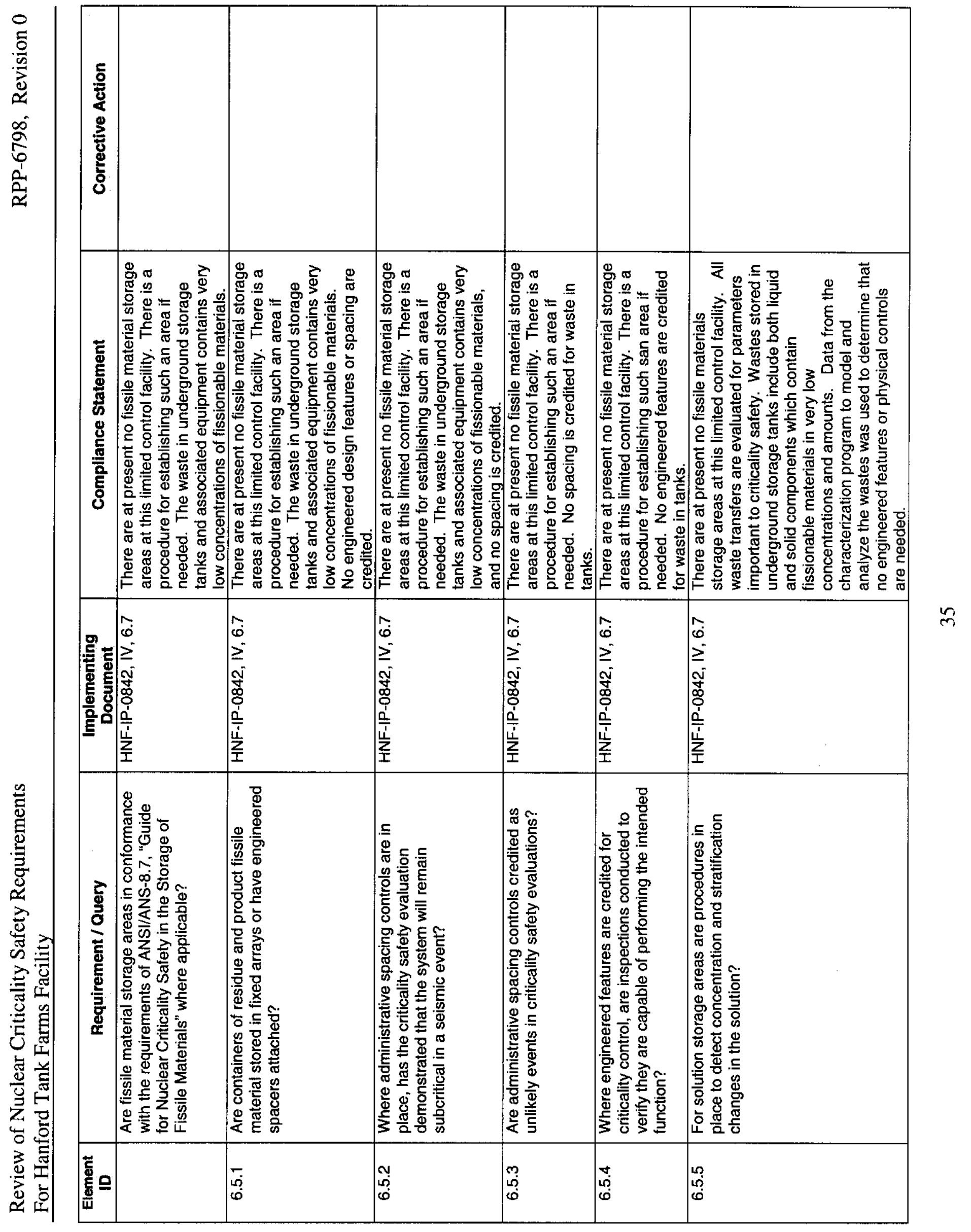




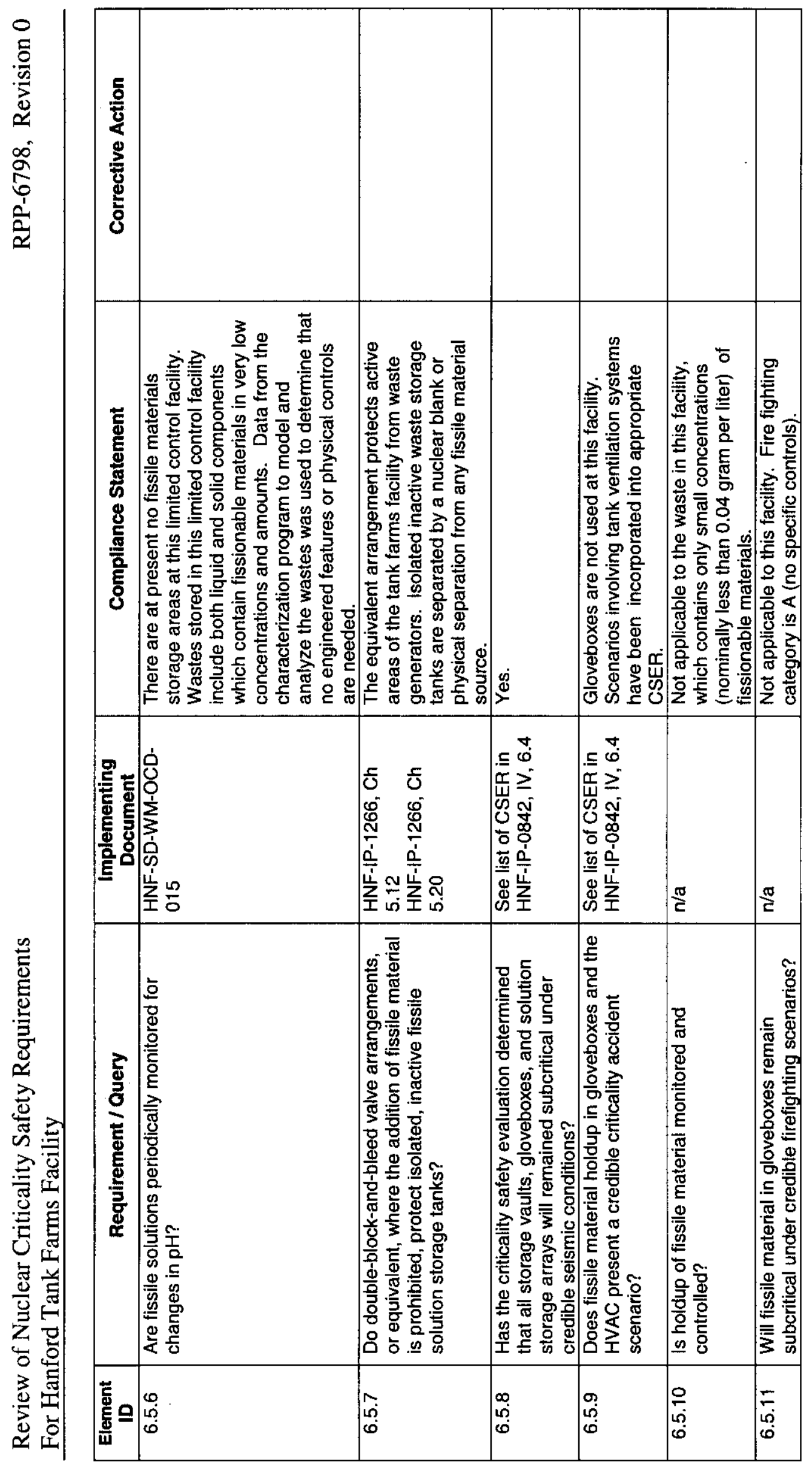




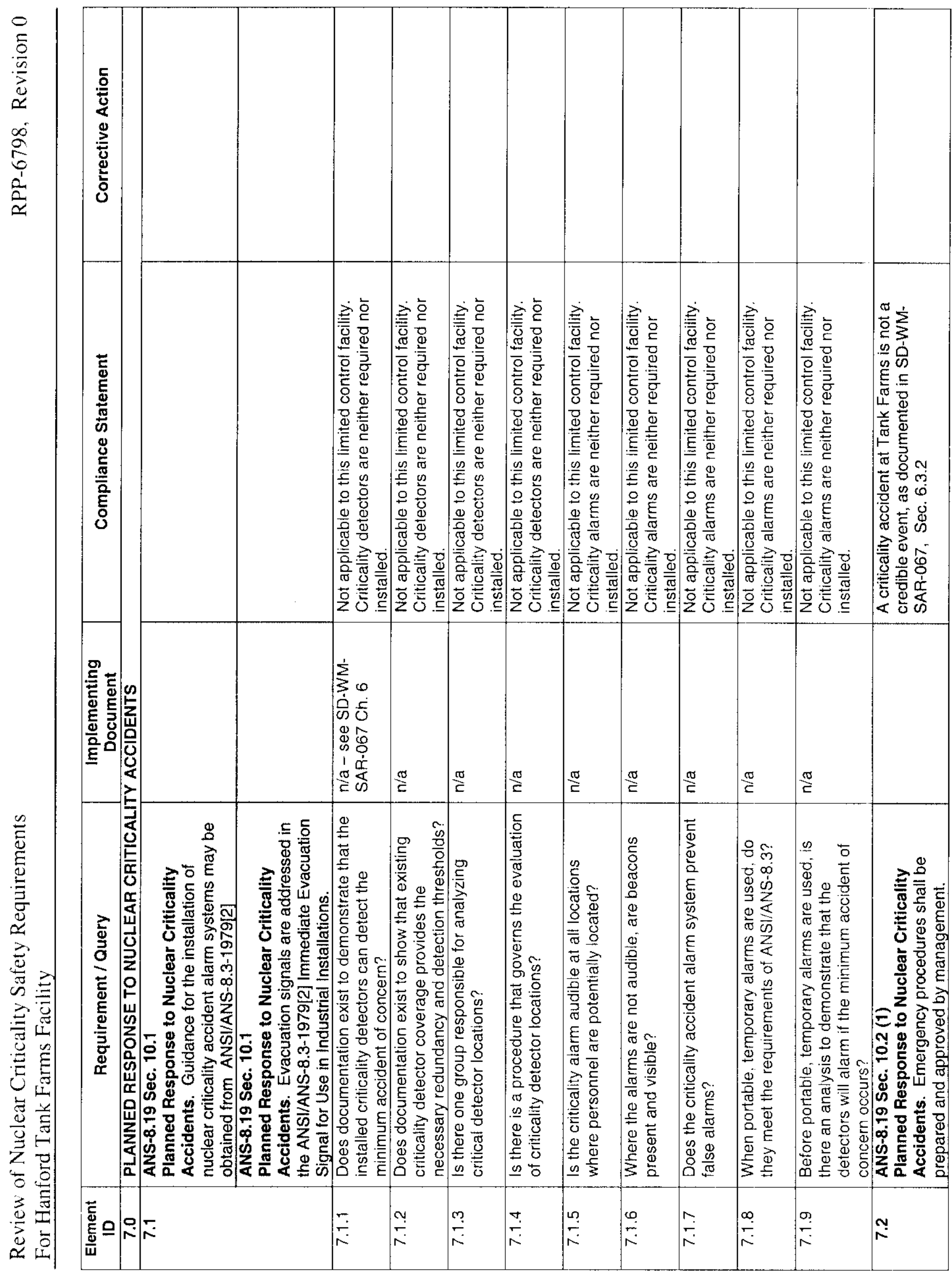




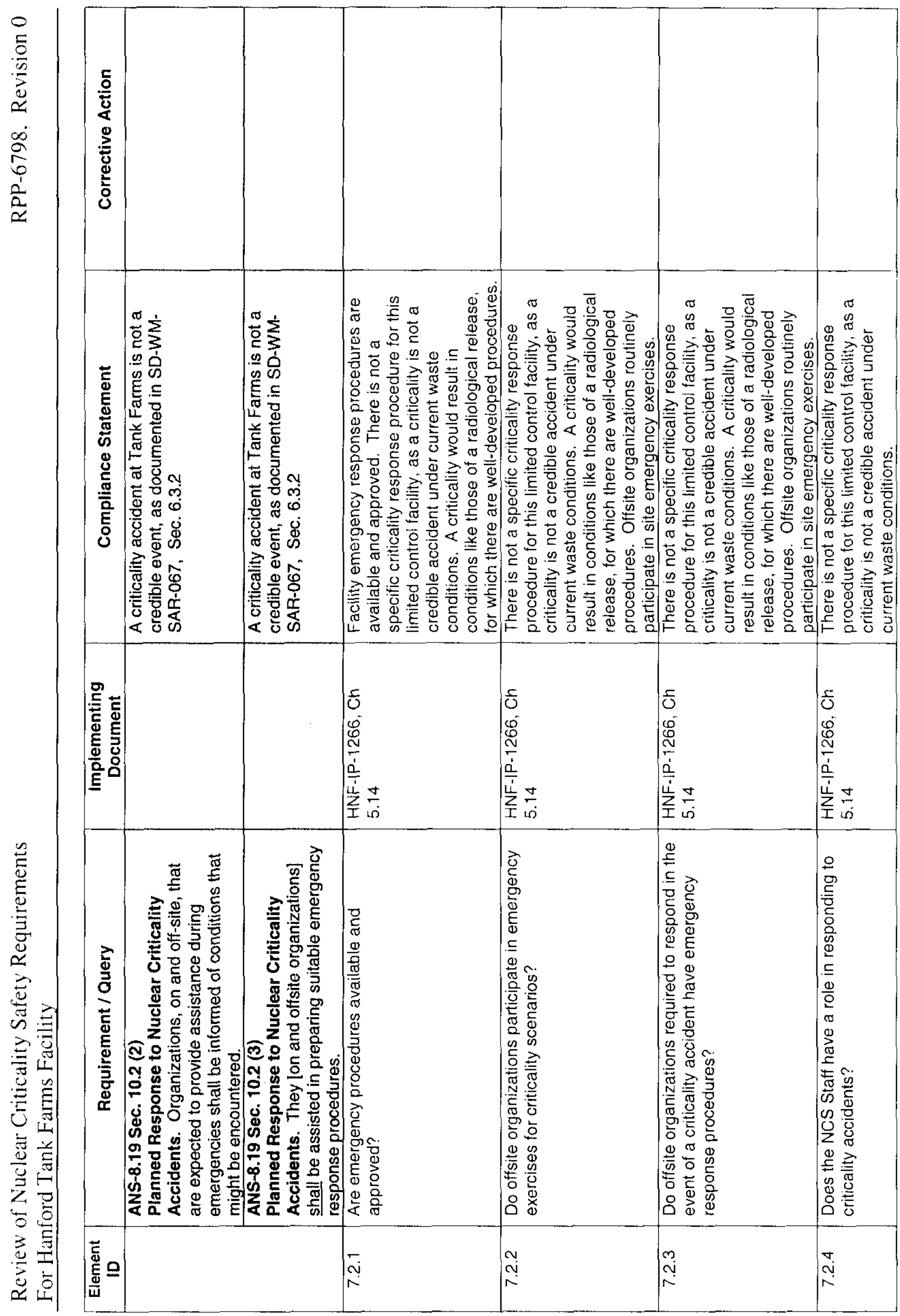




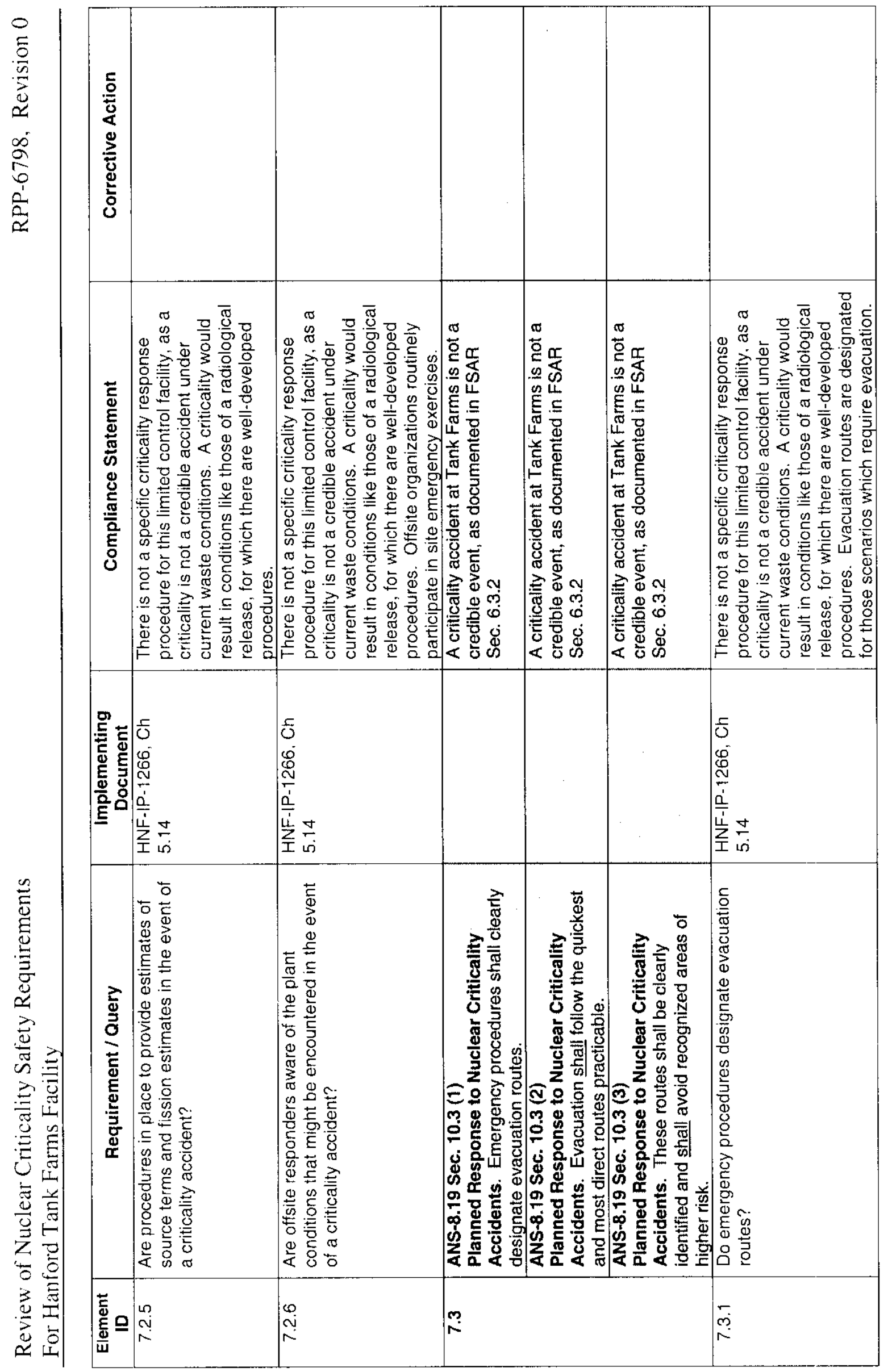




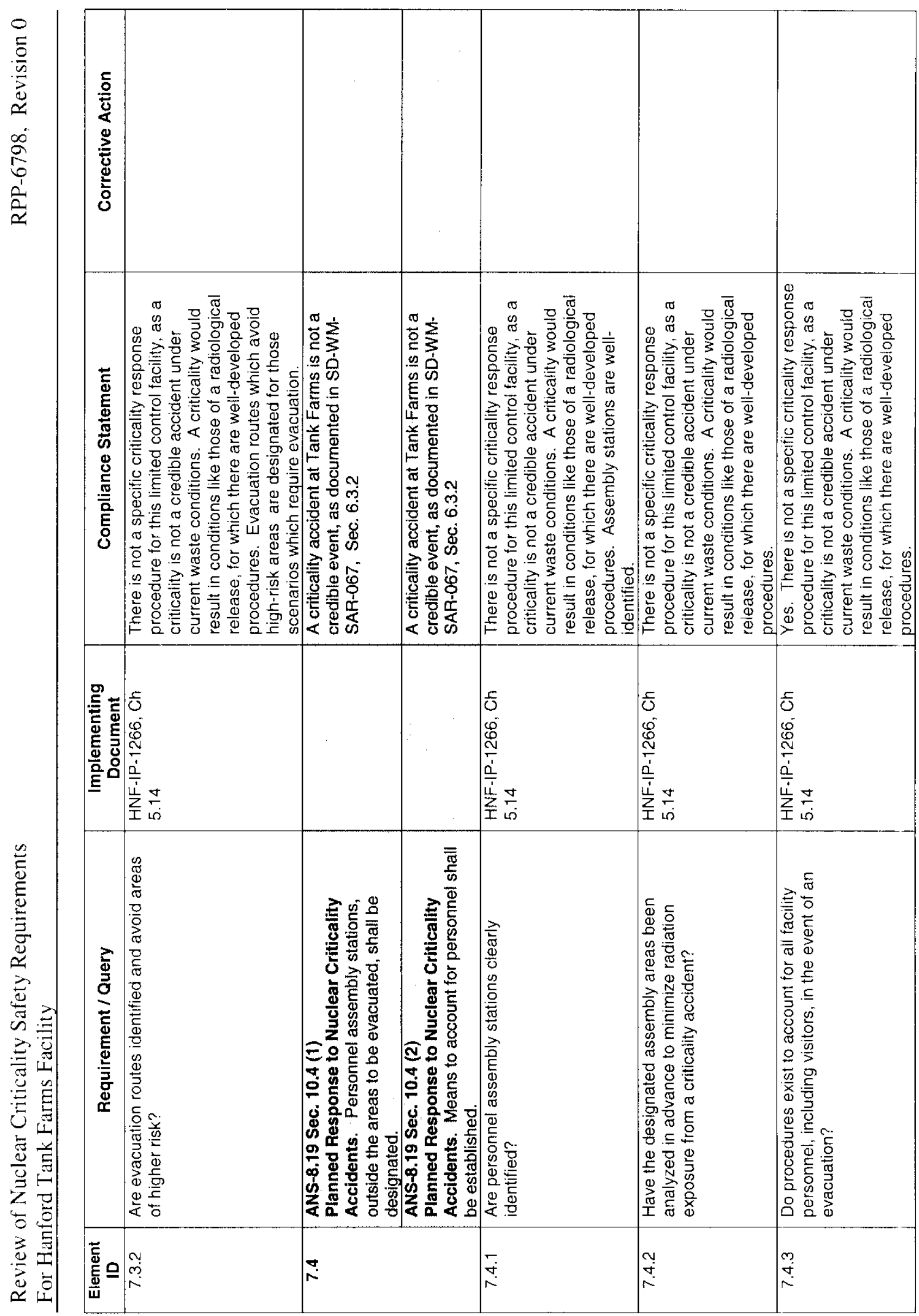




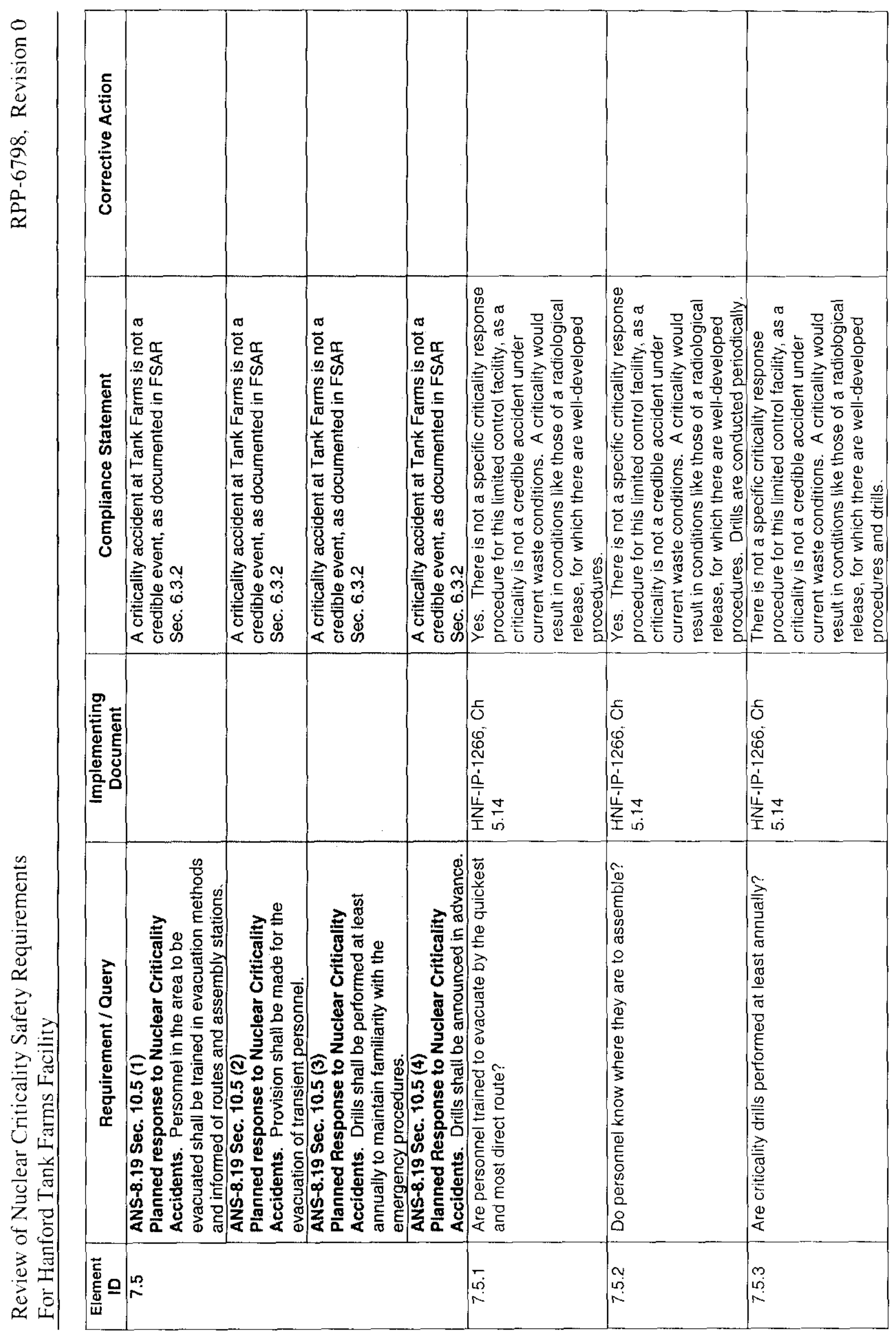




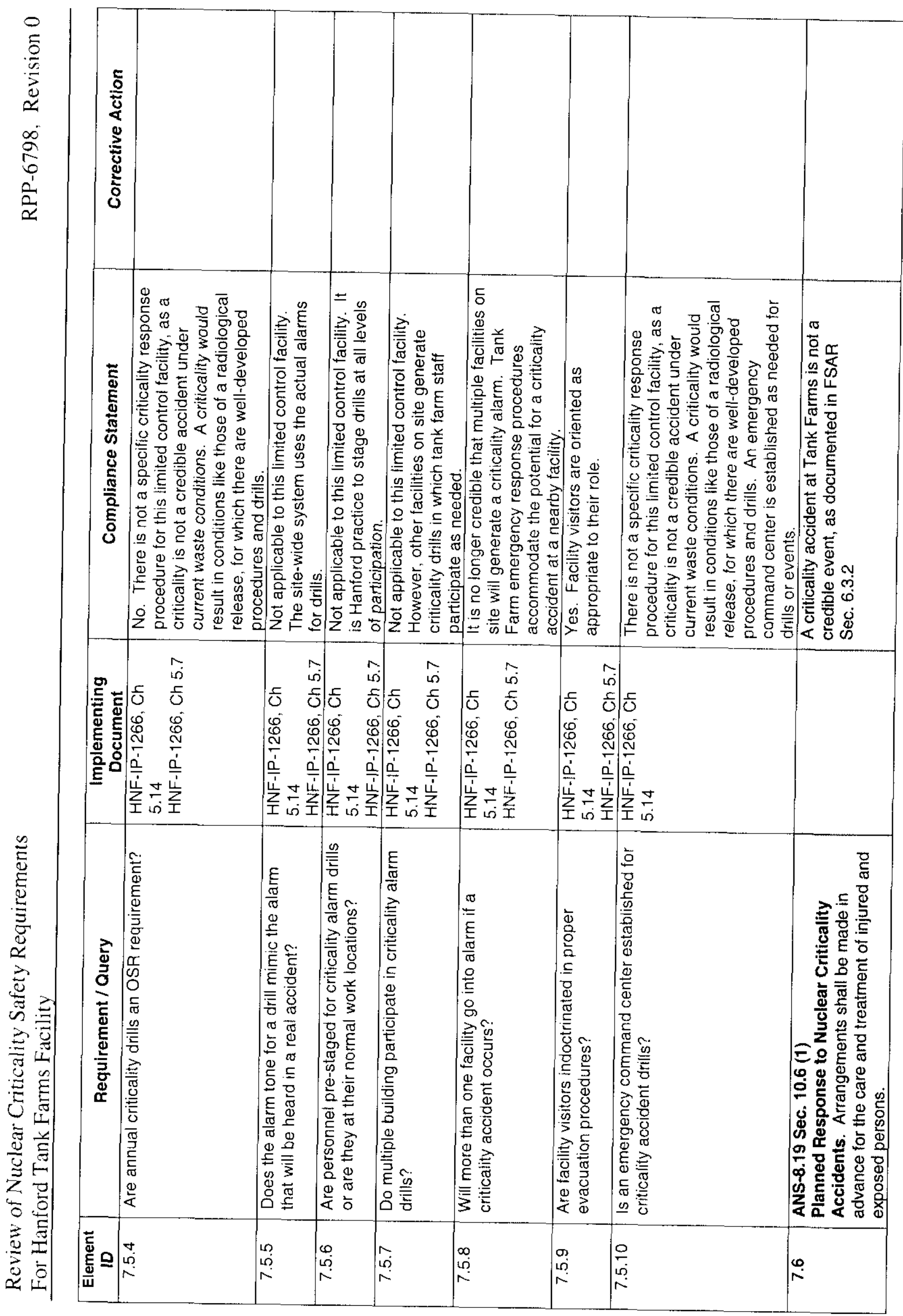




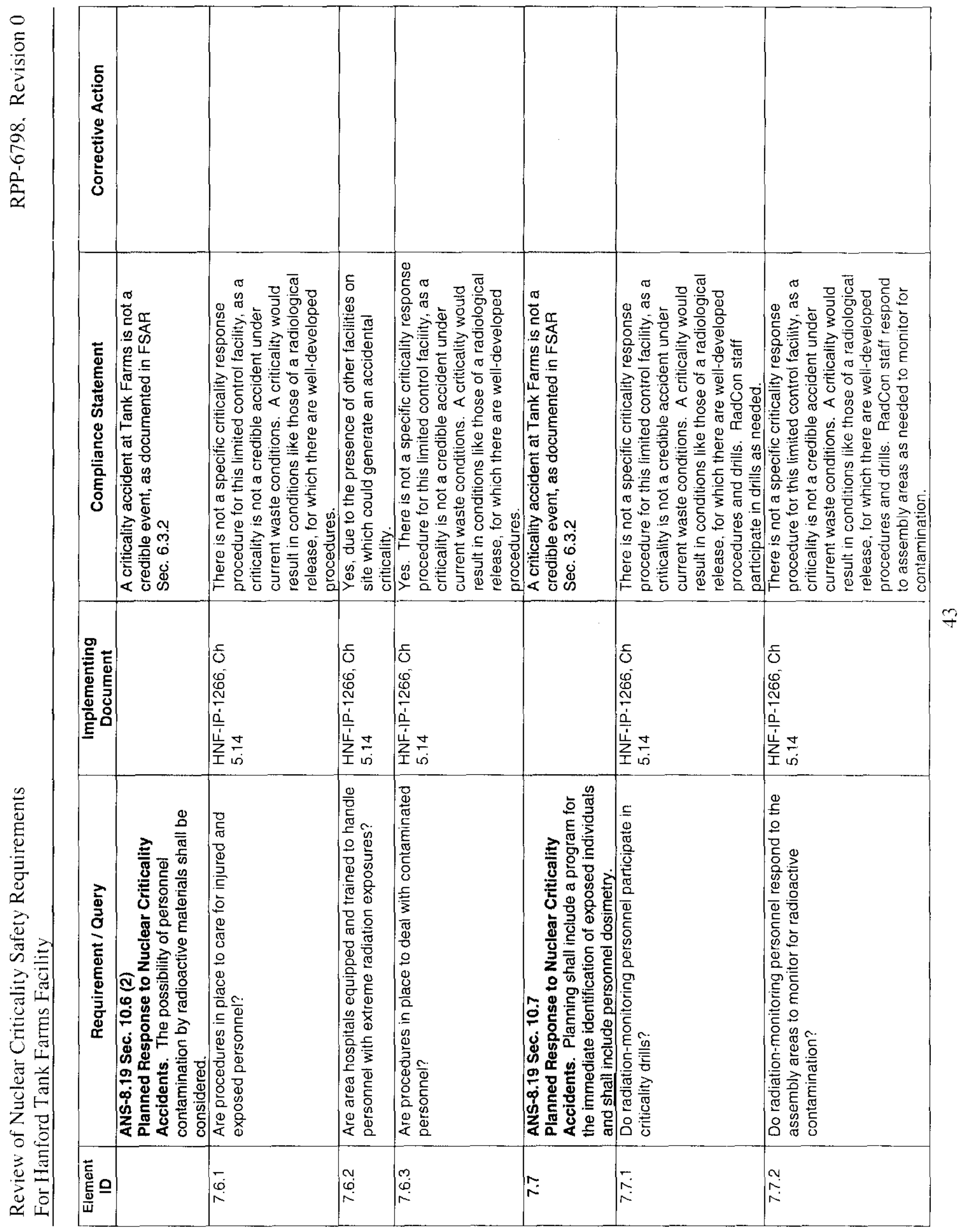




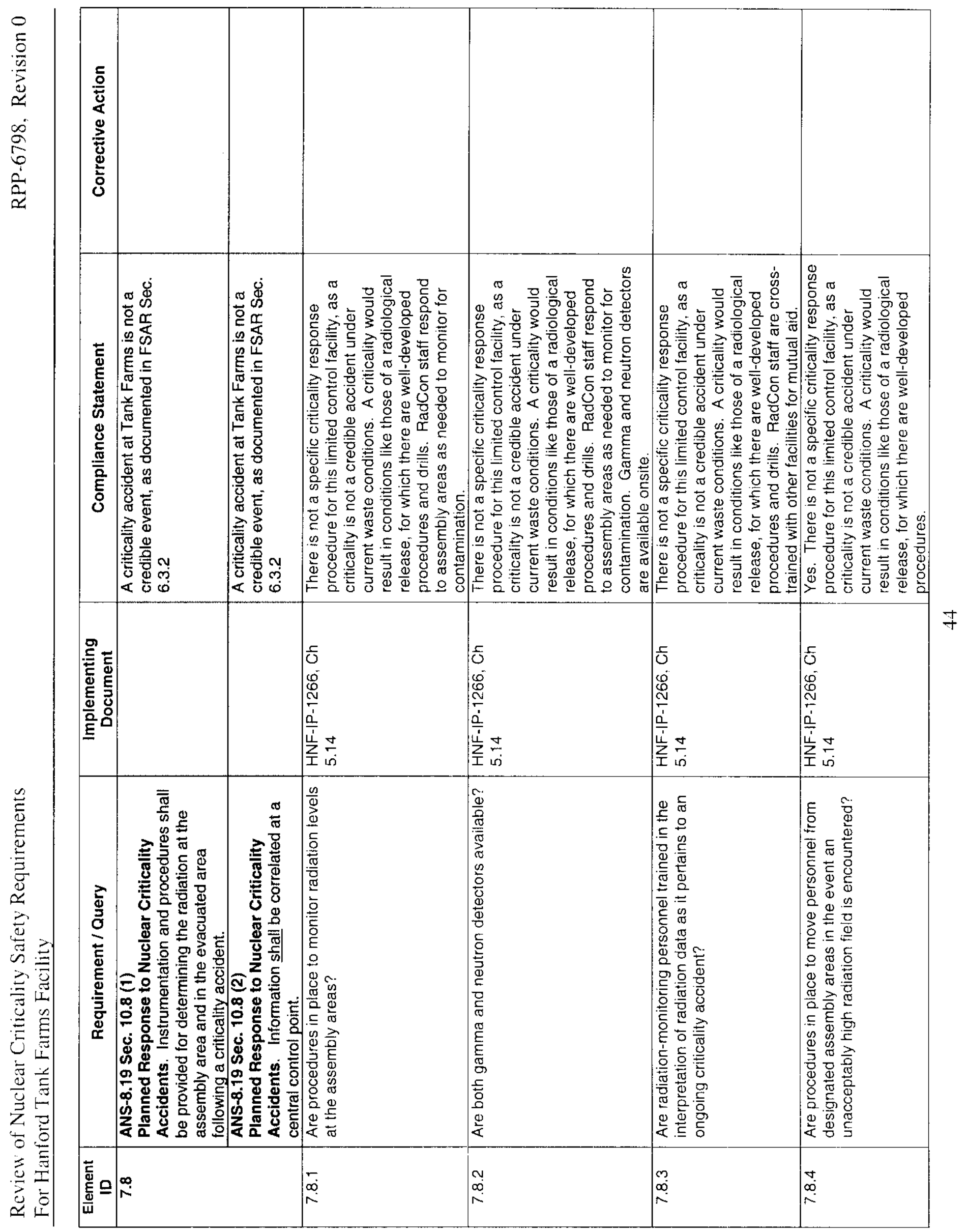




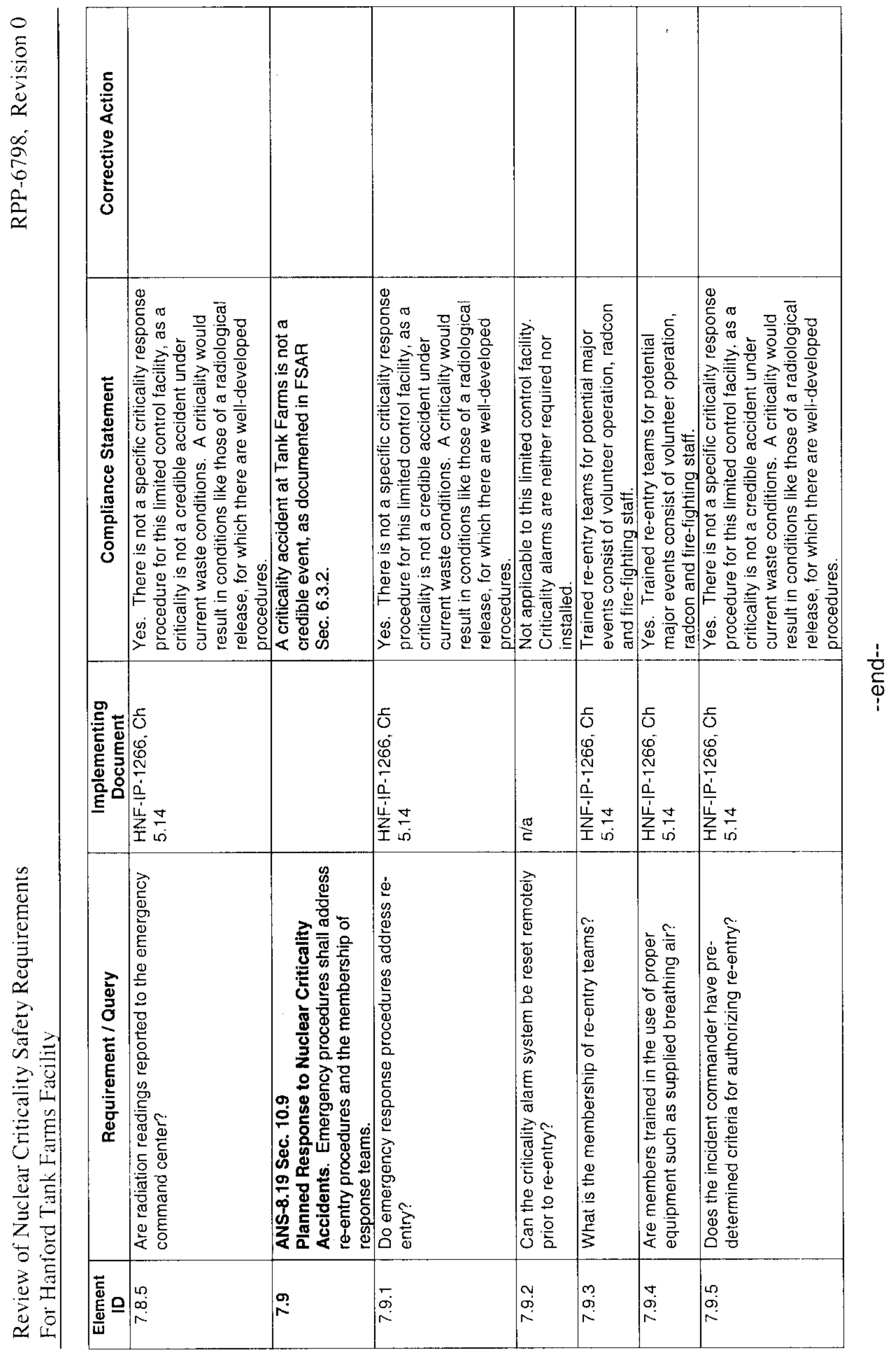




\subsection{REFERENCES}

DOE O 420.1, Facility Safety, 1996, Change 2, Department of Energy, Washington, D.C..

DOE 5480.24, Nuclear Criticality Safety, 1992, Department of Energy, Washington, D.C.

DOE, Workshop Handbook: Your Mission ... and Nuclear Criticality Safety, August 1999, Las Vegas, Nevada.

HNF-IP-0842, RPP Administration, current version as of May 10, 2000, CH2M HILL Hanford Group, Incorporated, Richland, Washington.

HNF-IP-1266, Tank Farms Operations Administrative Controls, current version as of May 10 , 2000, CH2M HILL Hanford Group, Incorporated, Richland, Washington.

HNF-SD-MP-SRID-001, 1999, High Level Waste Storage Tank Farms/242-A Evaporator Standards/Requirements Identification Document, Rev. 2, CH2M HILL Hanford Group, Incorporated, Richland, Washington.

HNF-SD-WM-SAR-067, 2000, Tank Waste Remediation System Final Safety Analysis Report, Rev. 1H, CH2M HILL Hanford Group, Incorporated, Richland, Washington.

HNF-SD-WM-TSR-006, 2000, Tank Waste Remediation System Technical Safety Requirements, Rev. 1H, CH2M HILL Hanford Group, Incorporated, Richland, Washington.

Internal Memo, E. J. Lipke to T. C. Geer, "Criticality Compliance," September 3, 1997, Attachment 2 “ 9454500, Tank Farms Compliance Assessment and Implementation Plan for DOE Order 5480.24 Nuclear Criticality Safety,” DE\&S Hanford, Richland, Washington.

Memorandum, T. J. Glauthier to Heads of Departmental Elements, "Nuclear Criticality Safety Self-Improvement Initiative," November 3, 1999, Department of Energy, Washington, D. C.

TWR-3721, M. C. Brady Rapp et al, Tank Waste Remediation System Nuclear Criticality Safety Program Management Review, April 1999, DE\&S Hanford Corporation, Richland, Washington.

WHC-SD-WM-TI-725, 1996, Tank Farm Nuclear Criticality Review, Rev. 0A, Westinghouse Hanford Company, Richland, Washington. 


\section{DISTRIBUTION SHEET}

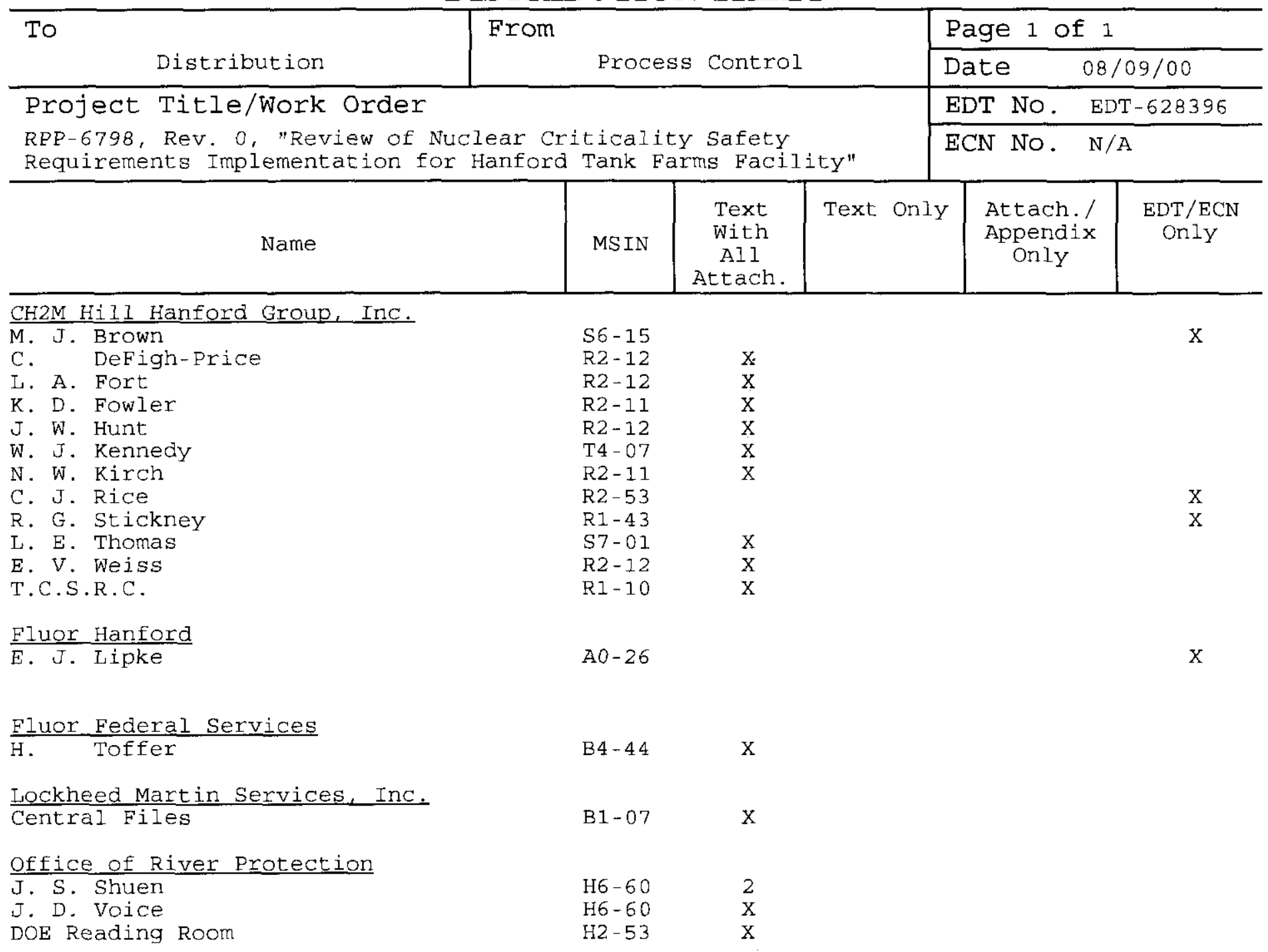

